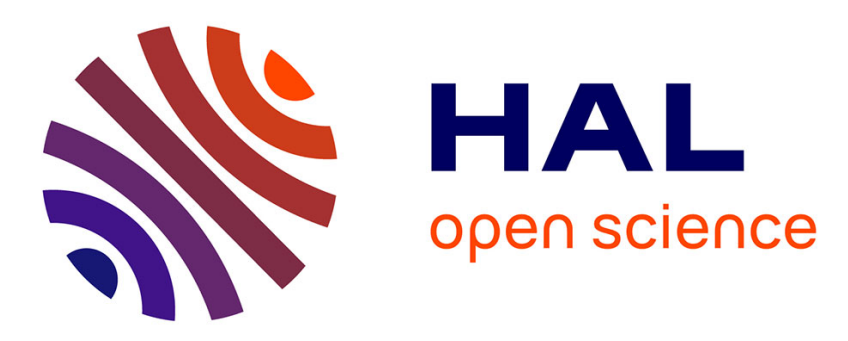

\title{
Fluid circulation in the depths of accretionary prisms: an example of the Shimanto Belt, Kyushu, Japan
}

Hugues Raimbourg, Maxime Vacelet, Claire Ramboz, Vincent Famin, Romain Augier, Giulia Palazzin, Asuka Yamaguchi, Gaku Kimura

\section{To cite this version:}

Hugues Raimbourg, Maxime Vacelet, Claire Ramboz, Vincent Famin, Romain Augier, et al.. Fluid circulation in the depths of accretionary prisms: an example of the Shimanto Belt, Kyushu, Japan. Tectonophysics, 2015, 655, pp.161-176. 10.1016/j.tecto.2015.05.023 . insu-01163834

\section{HAL Id: insu-01163834 https://hal-insu.archives-ouvertes.fr/insu-01163834}

Submitted on 16 Jun 2015

HAL is a multi-disciplinary open access archive for the deposit and dissemination of scientific research documents, whether they are published or not. The documents may come from teaching and research institutions in France or abroad, or from public or private research centers.
L'archive ouverte pluridisciplinaire HAL, est destinée au dépôt et à la diffusion de documents scientifiques de niveau recherche, publiés ou non, émanant des établissements d'enseignement et de recherche français ou étrangers, des laboratoires publics ou privés. 


\section{Accepted Manuscript}

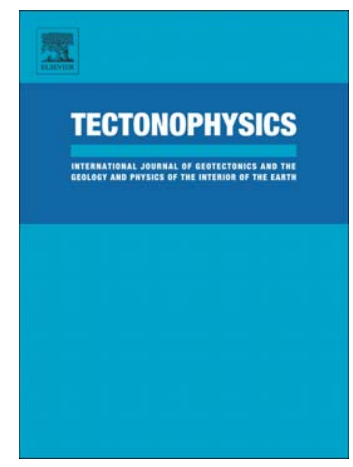

Fluid circulation in the depths of accretionary prisms: an example of the Shimanto Belt, Kyushu, Japan

Hugues Raimbourg, Maxime Vacelet, Claire Ramboz, Vincent Famin, Romain Augier, Giulia Palazzin, Asuka Yamaguchi, Gaku Kimura

PII:

S0040-1951(15)00290-5

DOI:

doi: $10.1016 /$ j.tecto.2015.05.023

Reference: $\quad$ TECTO 126639

To appear in: $\quad$ Tectonophysics

Received date: $\quad 24$ July 2014

Revised date: $\quad 6$ April 2015

Accepted date: 1 May 2015

Please cite this article as: Raimbourg, Hugues, Vacelet, Maxime, Ramboz, Claire, Famin, Vincent, Augier, Romain, Palazzin, Giulia, Yamaguchi, Asuka, Kimura, Gaku, Fluid circulation in the depths of accretionary prisms: an example of the Shimanto Belt, Kyushu, Japan, Tectonophysics (2015), doi: 10.1016/j.tecto.2015.05.023

This is a PDF file of an unedited manuscript that has been accepted for publication. As a service to our customers we are providing this early version of the manuscript. The manuscript will undergo copyediting, typesetting, and review of the resulting proof before it is published in its final form. Please note that during the production process errors may be discovered which could affect the content, and all legal disclaimers that apply to the journal pertain. 


\section{Fluid circulation in the depths of accretionary prisms: an example of the Shimanto Belt, Kyushu, Japan}

Hugues Raimbourg (1), Maxime Vacelet (2), Claire Ramboz (1), Vincent Famin (3), Romain Augier (1), Giulia Palazzin (1), Asuka Yamaguchi (4) and Gaku Kimura (5)

(1) Univ. d'Orléans, ISTO, UMR 7327, 45071, Orléans, France ; CNRS, ISTO, UMR 7327, 45071 Orléans, France ; BRGM, ISTO, UMR 7327, BP 36009, 45060 Orléans, France (2)

Centre de Géosciences, Mines ParisTech, Fontainebleau, France, (3) Laboratoire

Géosciences - IPGP, La Réunion University, Saint Denis, France, (4) Department of Ocean Floor Science, Atmosphere and Ocean Research Institute, University of Tokyo, Kashiwa, Chiba, Japan, (5) Department of Earth and Planetary Science, University of Tokyo, Tokyo, Japan.

Corresponding author: Hugues Raimbourg, hugues.raimbourg@univ־orleans.fr, Tel: $+33-238494789$ 


\section{Highlights:}

Two distinct fluids unraveled from deep quartz veins in a fossil accretionary prism

Local fluid intermittently replaced by pulses of external fluid with higher salinity and

$\mathrm{Al}$ content

$\delta^{18} \mathrm{O}$ signature of the fluid is lost by reequilibration; salinity and aluminum signatures much more persistent.

The source of the saline, external fluid is shallow water percolated to depth.

\section{Keywords}

Fluids

Subduction zones

Accretionary prisms

Cathodoluminescence

Quartz

Fluxes 


\section{1 -Abstract}

Accretionary prisms constitute ideal targets to study fluid circulation and fluid-rock interactions at depths beyond the reach of active margin deep drilling. The highest-grade rocks from the Shimanto Belt on Kyushu were buried under 3-5 kbars at $\sim 300^{\circ} \mathrm{C}$ (Toriumi and Teruya, 1988). They contain abundant quartz veins, formed throughout burial and exhumation and variably affected by brittle and ductile deformation.

Cathodoluminescence (CL) reveals the existence of two distinct types of quartz, characterized by a blue and brown color, respectively. CL-blue quartz fills macro-veins (width $\geq 10 \mu \mathrm{m}$ ), while CL-brown quartz is present in micro-veins (width $\sim 1-10 \mu \mathrm{m}$ ) and ductilely recrystallized domains. On the basis of microstructures, the fluids associated with the CL-blue and CL-brown quartz are interpreted as "external" and "local", respectively. Quartz growth rims of alternating CL colors as well as mutually cross-cutting veins show that the two fluids cyclically wetted the host rock.

From fluid inclusions analysis, the fluid associated with CL-blue quartz has a salinity similar to seawater, while the fluid associated with CL-brown quartz is less saline. In addition, CL-blue quartz is richer in aluminum than the CL-brown one. In contrast to the salinity/aluminum signature, the $\delta^{18} \mathrm{O}$ isotopic signature of both quartz types is 
similar and buffered by host rock. The difference between the preservation of the salinity signature of the fluid and the loss of its $\delta^{18} \mathrm{O}$ signature is explained by quicker exchange kinetics and larger host rock buffering capacity for isotopic reequilibration.

The "local" fluid, associated with CL-brown quartz, reflects the dilution of pore water by the pure water produced by prograde dehydration reactions of clay minerals. The "external" fluid associated with CL-blue quartz is interpreted as seawater or pore water from shallow (depth<1-2 $\mathrm{km}$ below seafloor) sediments. We propose that downward percolation of shallow water to depths $\sim 10 \mathrm{~km}$ is a transient process associated with mega-earthquakes.

\section{2-Introduction}

Hydrological models of accretionary prisms and subduction zones, in particular the distribution of fluid pressure (e.g. Saffer and Bekins (2006)), play a major role in our understanding of the margin dynamics (Le Pichon et al., 1993; Saffer and Tobin, 2011a). For instance, in the critical wedge model (Dahlen, 1984; Dahlen, 1990; Davis et al., 1983), which is the cornerstone of most studies of accretionary prisms, one the largest variability in prism dynamics lies in the fluid pressure along the basal décollement zone. 
Sources of fluid pressure are the compaction of porous sediments, as well as the release of water bound to minerals as a result of the increase in temperature (Kastner et al., 1991; Moore and Saffer, 2001). Fluid budgets at the scale of the whole subduction zone are dominated by bound water sources (Peacock, 1990; Van Keken et al., 2011), whereas the fluid budget in accretionary prisms reflects the dominance of a pore water source down to a depth of about 10-15km (Kastner et al., 1991).

In accretionary prisms, steady-state models of water production can be derived from compaction laws (Baldwin and Butler, 1985; Bray and Karig, 1985; Kominz and Pekar, 2001), assuming a conservation of the solid material and self-similar growth of the wedge by accretion at the trench (Bekins and Dreiss, 1992; Le Pichon et al., 1990; Saffer and Bekins, 1998). Such models provide estimates of the global flux out of the prism, which can be compared with the present-day fluxes, derived for example from heat flow measurements. This comparison, detailed in Kastner et al. (1991) and Le Pichon et al. (1991), revealed a large discrepancy between the two kinds of estimates, with the actual flux being an order of magnitude or more larger than the supply of water by sediment compaction. Possible ways out of such a discrepancy include shallow ( $\sim 2 \mathrm{~m}$ depth below seafloor), salinity-driven convection in areas focusing the flow (Henry et al., 1992), recharging of the décollement through seismic pumping (Sibson, 1975), as proposed by 
Le Pichon et al. (1991), or large-scale transport of meteoritic water (Kastner et al., 1991).

In any case, an additional influx of external fluids is necessary to match the flux out of accretionary prisms.

The geochemical features of pore fluids in drilled-core samples provide another argument to constrain the geometry of the fluid circulation. In particular, the presence of deep fluids circulating along the décollement is suggested by the $\delta^{13} \mathrm{C}$ of dissolved methane in Barbados (Vrolijk et al., 1990), the presence of propane (Morris and Villinger, 2006) or the isotopic signature of lithium in Costa Rica (Chan and Kastner, 2000). The low chloride anomaly observed in numerous subduction zones (Kastner et al., 1991) may also correspond in part to deep fluids, although their contribution is debated (Henry and Bourlange, 2004; Saffer and McKiernan, 2009).

At further depths, i.e. beyond $\sim 1 \mathrm{~km}$ below seafloor, circulating fluids are only constrained by fluid inclusions trapped in quartz or carbonate veins in fossil prisms. In most accretionary prisms, including the Shimanto Belt in Japan (Kondo et al., 2005; Raimbourg et al., 2014b; Sakaguchi, 1999), Kodiak Island in Alaska (Vrolijk et al., 1988) or the Franciscan Complex in California (Dalla Torre et al., 1996; Sadofsky and Bebout, 2004), fluid inclusions contain a mixture of low-salinity water and methane, for temperatures up to $\sim 300^{\circ} \mathrm{C}$. Fluid inclusions from higher-grade rocks are markedly 
different as methane is replaced by carbon dioxide, as was shown on a transect through the Central Alps by Mullis (1994). These studies, if they give a relatively consistent picture of the nature of the fluid, yields limited insights into the patterns of their circulation. Variations in pressure or redox state, possibly related to earthquakes (Vrojlik, 1987; Yamaguchi et al., 2011) or mixture of disequilibrium fluids (Raimbourg et al., 2014b) point to complex flow geometry.

To investigate further the question of fluid circulation in the depths of accretionary prisms, we have analyzed the quartz microstructures in metamorphic samples from the Shimanto Belt in Japan. The belt is a fossil, on-land analogue of modern accretionary prisms such as the Nankai Trough (Taira et al., 1988). The inner exposed metamorphic regions of the Shimanto belt enable the study of the deep domains of accretionary prisms. In the strongly deformed rocks of the Shimanto Belt, cathodoluminescence imaging, microstructures, fluid inclusion microthermometry, in-situ $\delta^{18} \mathrm{O}$ and major-element analyzes in quartz veins reveal the existence of two distinct sources of fluids. These two sources of fluids have critical implications for the models of fluid circulation in the depths of accretionary prisms.

\section{3-Geological setting and sampling strategy}

The Shimanto Belt is the exhumed part of a Cretaceous to present accretionary prism 
(e.g. Taira et al. (1988)). All samples were collected in the inner domains of the Shimanto Belt on Kyushu, Japan, along the Nobeoka Tectonic Line (NTL; Fig. 1). Samples analyzed here belong either to the mélange unit on top of the Hyuga Group (named hereafter Hyuga mélange) or to the foliated unit at the base of the Morotsuka Group (named hereafter foliated Morotsuka) (Imai et al., 1971; Murata, 1997). As these units experienced significant metamorphism (Imai et al., 1971), they are interpreted as the deep, i.e. $\sim 10-15 \mathrm{~km}$ depth, domains of an accretionary prism that has been exhumed after the prism grew seaward. Furthermore, the Hyuga mélange and the foliated Morotsuka units experienced a large magnitude of strain related to their former position near the décollement (Raimbourg et al., 2014a). They constitute therefore key targets to analyze the deformation and fluid circulation in the depths of a modern accretionary prism such as the Nankai Trough, where drilling is limited to the first two or three kilometers.

The Hyuga mélange and the foliated Morotsuka units are metasedimentary units mostly comprising phyllosilicates and quartz, with minor intercalated metabasite slivers and metaradiolarites (Raimbourg et al., 2014a). From the analysis of lenses of oceanic material embedded in the sedimentary matrix, metamorphic conditions were determined in the Hyuga mélange as $\sim 200-300^{\circ} \mathrm{C}$ and $3-5 \mathrm{kbars}$ (Toriumi and Teruya, 
1988) and slightly higher in the foliated Morotsuka. More precise estimates of the maximum temperature experienced by the sedimentary matrix were derived from illite crystallinity (Hara and Kimura, 2008; Mukoyoshi et al., 2009) or vitrinite reflectance (Kondo et al., 2005), yielding $250-300^{\circ} \mathrm{C}$ in the Hyuga mélange and $300-310^{\circ} \mathrm{C}$ in the foliated Morotsuka, i.e. a temperature gap up to $60^{\circ} \mathrm{C}$. As phyllosilicates, including illites, are part of the metamorphic foliation and late shear bands, illite crystallinity arguably is the best indicator of temperatures of deformation.

Micro- and macrostructures of deformation are described in detail in Raimbourg et al. (2014a); only the main structural features are summarized here. The foliated Morotsuka is made of very thin alternations of phyllosilicate-rich and quartz-rich layers, with scarce shear bands (Fig. 2). The Hyuga mélange has an overall block-in-matrix structure, where the blocks are $\mathrm{mm}$ to $\mathrm{dm}$-scale lenses of boudinaged sandstone beds or pure quartz domains, embedded in a matrix rich in phyllosilicates (Fig. 2). The foliation is defined by the preferential orientation of the phyllosilicates as well as the flattening of the blocks. In addition, ductile deformation is apparent through a pervasive array of shear zones composed mostly of phyllosilicates. The top-to-the-SE kinematics recorded in shear zones is consistent with the subduction below Japan throughout the Cenozoic (Faccenna et al., 2012; Müller et al., 2008), so that deformation is attributed to shearing 
at depth in the accretionary prism near the plate interface. Furthermore, the NTL separating the Huyga mélange from the foliated Morotsuka is a major discontinuity, in terms of metamorphic grade, in the Shimanto Belt (Hara and Kimura, 2008; Toriumi and Teruya, 1988). Its geometry and large displacement (it accommodates $\sim 50 \mathrm{~km}$, see the reconstructions in Raimbourg et al. (2014a)) make the NTL a large-scale out-of-sequence thrust comparable to the ones observed in the modern margin (Kondo et al., 2005).

In addition to a large magnitude of strain, the foliated Morotsuka and Hyuga mélange exhibit abundant quartz recrystallization features, which we focused on as an indirect marker of deep fluids. At the macroscopic scale, the most obvious evidence of such recrystallization is the ubiquitous quartz veins (Fig. 2). These veins, which localize preferentially in sand-rich layers or blocks (Fig. 2A), can be deformed ductilely (Fig. 2B) or can cut across ductile deformation structures, such as the metamorphic foliation in Morotsuka (Fig. 2C). The microscopic picture is somewhat more complicated. Quartz is first present as detrital grains, scarce and fine-grained in pelitic layers and more abundant in coarser-grained layers or blocks interpreted as remnants of boudinaged sand-rich sedimentary beds. In such settings quartz grains are scattered in a matrix of very fine-grained phyllosilicates (Fig. 3A). Second, veins of quartz are observed cutting 
across the phyllosilicate foliation (Fig. 3 and 4). Finally, domains of pure quartz parallel to the foliation are also present, forming either layers (in foliated Morotsuka) or elongated blocks (Hyuga mélange). In both cases, these domains show evidence for a large magnitude of strain, including necking, very elongated shapes of the grains (Fig. 3B) or dynamic recrystallization (Fig. 5B and C"). The distinction between veins and ductilely-deformed, foliation-parallel pure quartz domains is based on end-members, as all intermediate textures of veins exist. As a result, we interpret all the pure quartz domains, whatever their shape, as originating from quartz veins, which have been affected by variable degrees of ductile deformation. In such an interpretation, quartz domains elongated parallel to the foliation predate the main stage of deformation, while undeformed quartz veins postdate it. In summary, all the pure quartz domains correspond to hydrothermal quartz, in contrast to inherited, detrital quartz grains embedded in the phyllosilicate-rich matrix.

This interpretation based on textures is the primary link between quartz grains and deep fluids. We postulate that (1) except for detrital grains of sedimentary origin, all quartz grains have precipitated from fluids wetting the rock at depth, and (2) as some of the quartz domains are plastically deformed and some not, quartz precipitation encompasses most of the rock evolution, in particular the portion near peak burial 
metamorphic conditions.

\section{4-Analytical methods}

Samples shown on Fig. 1 were processed into thin sections (for optical microscopy,

cathodoluminescence, electronic and ion microprobe) and thick sections (for fluid inclusion) for the analysis of quartz. Thin sections are $\sim 30 \mu \mathrm{m}$ thick and diamond polished on their upper surface. Thick sections are $\sim 100-200 \mu \mathrm{m}$ thick and diamond polished on both surfaces. Thin sections were all cut parallel to the stretching lineation (defined by elongation of sandstone lenses or quartz veins) and perpendicular to the foliation (i.e. the X-Z structural plane).

\section{1-Cathodoluminescence}

Samples were placed in a vacuum chamber at an Argon pressure of $\sim 6010^{-3}$ mbar. They were irradiated by a cold cathode source electron gun provided by OPEA (France). Standard tension-current beam conditions were maintained at $\sim 13-15 \mathrm{kV}$ and $90-110$ $\mu \mathrm{A}$, respectively. The angle between the gun axis and horizontal was $18^{\circ}$. The chamber was placed on a simplified optical mount designed to minimize light absorption on the beam pathway. The optical stage was equipped with a Retiga 2000R 1394a cooled camera (captor size $1 \mathrm{inch}$, resolution $1600 \mathrm{x} 1200 \mathrm{pixel}^{2}$, square pixel size $7.4 \mu \mathrm{m}$ ). The luminescence of quartz being quite low, acquisition time was fixed to ca. 10s. When 
present, the strong luminescence of carbonate veins prevented the analysis of quartz.

\section{2-Ion microprobe}

Oxygen isotopic compositions were measured during three sessions by ion microprobe at

CRPG-CNRS (Nancy, France) using the Cameca IMS 1280. The analytical settings are the same as described in Rollion-Bard et al (2007). Briefly, the $\mathrm{Cs}^{+}$ions primary beam with an intensity of $\approx 4-5 \mathrm{nA}$ was focused on the samples to a spot $\approx 25 \mu \mathrm{m}$-long and $\approx 10$ $\mu \mathrm{m}$-wide. To compensate for charge effect, a normal incidence electron gun was used. The entrance slit was set to a width of $80 \mu \mathrm{m}$, field aperture was $3000 \mu \mathrm{m}$, and the multicollection slit $n^{\circ} 1$ was used. These settings result in a mass resolution of $\approx 3000$, sufficient to resolve the interference peaks. Measurements of oxygen isotopes were performed in multicollection mode using two off-axis Faraday Cups (L'2 and H1) that were inter-calibrated before each analytical session. Measurements were performed with typical counts of $3.10^{9}$ counts per second for ${ }^{16} \mathrm{O}^{-}$. Acquisition sequences consist of $60 \mathrm{~s}$ of presputtering and then 30 cycles of $3 \mathrm{~s}$ each.

During the sessions, the internal error was always better than $0.1 \%$ ( $\left(2 \sigma_{\mathrm{n}}\right.$, with $\mathrm{n}$ being the number of cycles). The external reproducibility was estimated by multiple measurements of one in-house quartz reference material (NL 615, $\delta^{18} \mathrm{O}=18.4 \%$, Marin et al (2010)) and one international reference material (NBS-28, $\delta^{18} \mathrm{O}=9.58 \%$, 
Gonfiantini et al (1995)), and was $\pm 0.11, \pm 0.24$ and $0.44 \%$ ( $1 \sigma)$, depending on the session. The results are expressed with respect to the Standard Mean Ocean Water (SMOW).

\section{3-Major elements mapping}

Electron probe micro-analysis (EPMA) X-ray mapping was carried out using the Cameca SX Five at ISTO (Orléans, France), with a focused beam and analytical current conditions of $15 \mathrm{kV}$ and $50 \mathrm{nA}$. The concentration of aluminum was quantified with the Ka ray, on the TAP crystal. Step size was 4 microns in both directions and the dwell time $0.3 \mathrm{~s}$. Point analyses were performed with a focused beam and analytical current conditions of $15 \mathrm{kV}$ and $6 \mathrm{nA}$.

\section{4-Fluid inclusions analyses}

\subsubsection{Apparatus and uncertainties}

Fluid inclusion microthermometric measurements were carried out using the THMS-600 Linkam heating-cooling stage at ISTO (Orléans, France). Further details on apparatus and measurement conditions can be found in Raimbourg et al (2014b). The temperature accuracy for these measurements is around $\pm 1^{\circ} \mathrm{C}$ over the whole temperature range of investigation, from -120 to $+300^{\circ} \mathrm{C}$. The range of temperatures around $0^{\circ} \mathrm{C}$, relevant for ice melting temperature of aqueous inclusions, was calibrated 
by using synthetic inclusions of pure water (freezing point at $0^{\circ} \mathrm{C}$ ) and water $+\mathrm{CO}_{2}$ inclusions (melting point of $\mathrm{CO}_{2}$ at $-56.6^{\circ} \mathrm{C}$ ), according to the procedure detailed in $\mathrm{El}$ Mekki-Azouzi (2010). Measurements of ice melting temperature, repeated over several sessions, on the same reference sample containing synthetic, pure water inclusions, yielded differences of the order of $0.2^{\circ} \mathrm{C}$. In addition, measurements on synthetic, pure water inclusions, over different reference quartz samples of various thickness (200 to 600 microns) and shapes yielded differences as large as $0.6^{\circ} \mathrm{C}$ between the samples. As the rock slabs containing our natural fluid inclusions have various shapes and thickness, we estimate therefore the uncertainty of freezing stage measurement of ice melting temperatures as $\sim 0.8^{\circ} \mathrm{C}$.

\subsubsection{Choice of the fluid inclusions}

Fluid inclusions have a very variable density, from rare and scattered in optically clear quartz grains to a dense network of fluid inclusions in cloudy quartz (Fig. 3B). Fluid inclusions typically range from a few up to $5 \mu \mathrm{m}$ in diameter, in rare cases up to $10 \mu \mathrm{m}$. Shapes range from elliptical to very irregular. They present two phases at ambient temperatures and correspond to a mixture of salt water and methane (Raimbourg et al., 2014b). Due to the generally high density of inclusions, it is most often difficult to distinguish the nature (i.e. primary, secondary or pseudo-secondary) of the fluid 
inclusions. However, locally fluid inclusions are organized as planes (i.e. secondary inclusions) corresponding to healed fractures. In some cases, quartz grains show growth rims with a variable density of inclusions (Fig. 6). The latter microstructure shows the strongest correspondence of fluid inclusions to CL colors. In addition, we have used secondary fluid inclusions when they can be unambiguously associated with one kind of quartz: For example, trails of fluid inclusions contained by and parallel to a vein of homogeneous, CL-blue quartz were considered as contemporaneous with the precipitation of the vein and therefore associated with its attending fluid. Compared with traditional fluid inclusion studies, which rely only on primary fluid inclusions, the observation by CL of vein filling enable to associate secondary fluid inclusions to one quartz or the other and therefore to the corresponding fluid. This is absolutely necessary in the present study, as most of the structures observed are fracture filling, for which secondary fluid inclusions are the best records of the associated fluids. All the fluid inclusions studied belong to the Hyuga mélange unit and come from quartz veins postdating the ductile deformation stage, so that fluid inclusions have not been deformed after trapping.

For the chosen fluid inclusions, we measured ice melting temperature $\mathrm{T}_{\mathrm{mi}}$ (where the last crystal of ice melts into the liquid) and homogenization temperature $\mathrm{T}_{\mathrm{h}}$ (where the 
bubble of gas vanishes by dissolution into the liquid). Th were easily assessed, as gas bubbles are agitated by brownian motion. In contrast, the crystal of ice was not directly observed. Its disappearance can only be inferred from a movement of the gas bubble. In most fluid inclusions, when the last crystal melted, the gas bubble, which was immobile at lower temperature, moved to a new position in the inclusion and was then immobile upon temperature increase. We systematically checked the reproducibility of the phenomenon to associate it with the ice melting phase transition.

\section{5 -Results}

\section{1-Occurrences of quartz and relation to CL colors/fluids}

The large areas of pure quartz, when analyzed by CL, vary between two end-member colors, brown and blue. The blue component of the color rapidly vanishes with exposure to the CL electron beam, as can be seen in successive pictures (with a typical exposure time of 10s) taken on the same area. Areas with a bright CL-blue color in the first picture show an evolution in subsequent pictures to a darker blue and eventually to brownish/violet shades. In contrast, the brown component of CL-color does not vary with exposition time: Successive pictures of the same CL-brown quartz area do not show any significant variation. 
Quartz microstructures unraveled by CL and optical microscopy, as well as their relation with the two CL colors ("CL-blue" and "CL-brown"), are summarized in the following sections.

\subsubsection{Deformation structures}

A) Veins: Most of the veins are restricted to the sandstone or quartz domains

(e.g., Fig. 2) and only the largest cut across the phyllosilicate domains. Veins apparent in optical microscopy ("macro-veins") are at least tens of $\mu \mathrm{m}$ wide and are visible within the quartz domains through the difference in density of fluid inclusions (Fig. 3B'). CL highlighted a smaller range of veins ("micro-veins"), with a thickness of a few $\mu \mathrm{m}$, which are pervasive in many quartz domains (Fig. 4). The quartz within the veins is often crystallographically continuous with grain fragments in the vein walls. The CL colors are correlated with the size of the veins: macro-veins are filled with CL-blue quartz (Fig. 3); micro-veins are filled with CL-brown quartz (Fig. 4). Most of the CL-blue veins are subsequently crosscut by CL-brown micro-veins (Fig. 4A). In some cases, micro-veining is so pervasive that the original CL-blue quartz is only preserved as patches surrounded by a CL-brown matrix, yielding a patchy CL color (Fig. 4B). Due to micro-veining, the original CL-blue color of macro-veins vanishes with time: where successive generations of macro-veins can be recognized, CL-blue quartz is best preserved in the youngest 
generation (Fig. 3A).

B) Ductilely-deformed domains: In samples from the Hyuga mélange (Fig. 5A and B), ductile deformation is apparent in large, elongated grains (Fig. 5A, domain 1) as well as recrystallized grains of various sizes (Fig. 5A, domain 3). Recrystallization proceeds mostly from bulging of grain boundaries, leading to their serrated shapes (Fig. 5B). Recrystallized grains (Fig. 5A, domain 3) appear to lose the fluid inclusions that were present in parent grains (Fig. 5A, domains 1-2). CL colors match the distribution of recrystallization; parent grains have a patchy CL-blue color, while recrystallized grains are homogeneously CL-brown. In samples from the slightly higher grade foliated Morotsuka (Fig. 5C), recrystallized grains are dominant and are also characterized by a much lower density of fluid inclusions than parent grains. CL colors match the increase in recrystallization, as quartz domains are almost completely and homogeneously CL-brown.

\subsubsection{Growth structures}

Grain growth rims can be observed in quartz domains that are not internally deformed and appear to have postdated the main stage of deformation (Fig. 6). Rims appear in CL as alternating CL-blue and CL-brown quartz bands of variable width.

In summary, CL-blue quartz precipitates as macro-vein filling or as growth bands on 
idiomorphic crystals. CL-brown quartz precipitates also as growth rims or as micro-vein

filling. The recrystallization of quartz grains during plastic deformation is accompanied by a change in color towards a homogeneous CL-brown color.

\section{2-Chemical features of the CL-blue and CL-brown quartz}

The characteristics of the CL-blue and CL-brown quartz were further constrained using optical and electronic microscopy, secondary ionization mass spectroscopy (SIMS) and microthermometry.

\subsection{1-Relations between the fluid types and the fluid inclusions distribution}

The density of fluid inclusions (FI) is primarily dependent on the relative age of the host quartz, i.e. younger veins contain fewer FI than quartz domains they cut across (Fig. 3B), irrespective of the CL color of vein/host quartz (Fig. 6A vein "V5", Fig. 6B veins "Vbl" and "Vbr"). There is in general no obvious match between CL colors and FI density (Fig. $6 \mathrm{~B}$ and $6 \mathrm{C})$. In the particular cases where growth rims are preserved, rims of CL-blue quartz have typically a larger density of fluid inclusions than CL-brown ones (Fig. $6 \mathrm{~A}-\mathrm{B})$.

\subsection{2-Microthermometric properties}

The results of microthermometric analyses show contrasting results for $\mathrm{T}_{\mathrm{h}}$ and $\mathrm{T}_{\mathrm{mi}}$ (Fig.

7). Temperatures of ice melting show a systematic difference, with fluid inclusions in 
CL-blue quartz having slightly lower $\mathrm{T}_{\mathrm{mi}}$ (peak around $-2.9^{\circ} \mathrm{C}$ ) than in CL-brown quartz (peak around $-1.7^{\circ} \mathrm{C}$ ). In contrast, there is no significant difference in $\mathrm{T}_{\mathrm{h}}$ between CL-brown and CL-blue quartz and $\mathrm{T}_{\mathrm{h}}$ are principally distributed between 170 and $280^{\circ} \mathrm{C}$. As all the samples considered belong to the Hyuga mélange unit, $\mathrm{T}_{\mathrm{h}}$ is approximately the same as the maximum temperature experienced by the rocks ( $\mathrm{T}_{\max } \sim 250-280 \pm 30^{\circ} \mathrm{C}$ ), measured by vitrinite reflectance or illite crystallinity (Hara and Kimura, 2008; Kondo et al., 2005; Mukoyoshi et al., 2009).

\subsection{3-Oxygen isotopic signature}

There is typically no difference in $\delta^{18} \mathrm{O}$ between CL-blue and CL-brown quartz, both for a late-stage CL-blue vein cutting across ductilely elongated CL-brown quartz (Fig. 8A) and for alternating CL-blue and CL-brown quartz growth rims (Fig. 8B). Considering all the samples together, the range of $\delta^{18} \mathrm{O}$ variations is $\sim 3 \%$ (Fig. 9). In contrast, variations between CL-blue and CL-brown quartz in a given sample are one order of magnitude smaller.

\subsection{4-Aluminum content}

EPMA maps show systematically a higher content of aluminum in CL-blue quartz (Fig. 10). EPMA punctual analyses on the same area yielded an average concentration of 0.3 wt\% $\mathrm{Al}_{2} \mathrm{O}_{3}$ in CL-blue quartz, while the concentration in CL-brown quartz was always 
below the detection limit of $\sim 0.05 \mathrm{wt} \%$ for the analytical conditions used.

\title{
6-Discussion
}

\author{
6.1-Circulating fluids: signature and origin \\ 6.1.1-"External” vs. "local" fluid: textural evidences
}

The use of CL on large areas of pure quartz formed at depth enabled two different types

to be distinguished. The CL-brown quartz is observed in recrystallized domains (Fig. 5).

Recrystallization proceeds in part through grain boundary migration, as is suggested by the observation of serrated grain boundaries (Fig. 5B). As grain boundaries sweep through the grains, they enable the exchange of fluid/elements between grain interiors and surrounding medium. The evidence for such exchanges of fluid is the scarcity of fluid inclusions preserved in recrystallized domains with respect to non-recrystallized domains (Fig. 5A'). The transfers of elements and fluids associated with grain boundary mobility enables therefore the quartz to equilibrate with the surrounding fluid, so that the CL-brown quartz corresponds to the "local" fluids that assisted plastic deformation. This hypothesis is further supported qualitatively by respective thickness of the veins: brown CL-quartz is associated with micro-veins, hence a fluid network with narrow crack apertures and low permeability that enables only very local fluid transport. In contrast, the crystallization of CL-blue quartz in thicker veins points to a much more 
permeable network that enables the influx of a more external source of fluids. Note that CL observations show no evidence for a multistage opening/filling of any given vein described here; in the present case, the present vein thickness is therefore a good approximation of the vein aperture and network permeability at the time of opening. This is not the case when crack-seal texture is present (for example in the Kodiak accretionary prism (Fisher and Brantley, 2014; Fisher et al., 1995)), in which case there is no direct relationship between vein final thickness and aperture at the time of opening.

Finally, alternating CL-blue and CL-brown quartz rims (Fig. 6 and 8C), as well as multiple crosscutting relationships between growth rims and veins of CL-blue and CL-brown quartz (Fig. 3A and 6) show that the two different fluids (and corresponding CL-brown and CL-blue quartz) alternate over many cycles throughout the rock evolution at depth. A summarizing sketch of rock-scale fluid circulations is shown in Fig. 11.

\subsection{2-Homogenization temperatures}

To interpret homogenization temperatures $T_{h}$ in terms of in-situ, paleo-temperatures of fluid trapping $T_{\text {trap }}$, we observe that $(1) T_{h}\left(\sim 170-280^{\circ} \mathrm{C}\right)$ is similar to peak rock temperatures $\mathrm{T}_{\max }\left(\sim 250-280 \pm 30^{\circ} \mathrm{C}\right)$ and $(2)$ the density of fluid inclusions is so high 
that it is unlikely that fluids much hotter than host rock circulated without affecting $\mathrm{T}_{\text {max. }}$ As a result, homogenization temperatures measured in the lab adequately represent paleo-temperatures of the fluid at depths (i.e. $T_{h} \sim T_{\text {trap }} \sim T_{\max }$ ).

Temperatures of the two fluids when they were circulating at depth are similar (Fig. 7), which further supports the model of a cyclic pattern of fluid circulations proposed in Fig. 11 on the basis of repetitive alternations of CL-blue and CL-brown quartz (Fig. 3 and 6). The two quartz/fluids do not correspond to two distinct stages in terms of tectonic or metamorphic history, but they rather show alternating wetting fluids near the peak temperature conditions.

\subsection{3-Interpretation of $T_{m i}$ in terms of salinity}

$\mathrm{T}_{\mathrm{mi}}$ reflects the salinity of the fluid; typical modern seawater has salinity of $35 \mathrm{wt} . \%$, which depresses $\mathrm{T}_{\mathrm{mi}}$ with respect to pure water down to $-1.9^{\circ} \mathrm{C}$ (Horne, 1969). Although seawater has a complex chemistry and many other solutes than the major $\mathrm{Na}^{+}$and $\mathrm{Cl}^{-}$, in terms of $\mathrm{T}_{\mathrm{mi}}$, it is approximately equivalent to a solution containing $35 \mathrm{wt}$.\% of $\mathrm{NaCl}$. Rather than modern seawater, Early Miocene seawater, with a salinity in the range 37-39 wt.\%o (Hay et al., 2006), provides a better estimate of seawater contemporaneous with vein formation, if one considers that the veins are associated with the main tectonic stage of deformation (Raimbourg et al., 2014a). The addition of $\mathrm{CH}_{4}$ to salt water also depresses $\mathrm{T}_{\mathrm{mi}}$, with a 
dependence we estimated with the software Fitane (Raimbourg et al., 2014b), using the model for density of aqueous solutions by Mao and Duan (2008) and the $\mathrm{CH}_{4}$ solubility model by Duan et al. (1992). To estimate the $\mathrm{CH}_{4}$ concentration in aqueous fluid inclusions from the Hyuga mélange, one can note that another kind of inclusions, rich in methane, was described in the same quartz veins (Kondo et al., 2005), implying that at some stage the aqueous fluid was saturated in methane and $\mathrm{CH}_{4}$ was present as a free phase. We consider therefore the solubility of methane in salt water for $250^{\circ} \mathrm{C}$ and $\mathrm{P} \sim 2 \mathrm{kbars}$, of the order of $1.5 \mathrm{~m}_{\mathrm{CH}_{4}}$ (Duan and Mao, 2006), as a good approximation of $\mathrm{CH}_{4}$ concentration in the aqueous fluid inclusions. $\mathrm{T}_{\mathrm{mi}}$ in a fluid inclusion containing a mixture of seawater (pure $\mathrm{H}_{2} \mathrm{O}$ and 37-39 wt.\% $\mathrm{NaCl}$ ) and dissolved methane in a proportion of $1.5 m_{\mathrm{CH}_{4}}$ is therefore -2.6 to $-2.7^{\circ} \mathrm{C}$ (see grey rectangle in Fig. 7). For comparison, three other reference $\mathrm{T}_{\mathrm{mi}}$ are shown in Fig. 7, for mixtures of $\mathrm{H}_{2} \mathrm{O}+1.5 \mathrm{~m}_{\mathrm{CH}_{4}}$ and dissolved $\mathrm{NaCl}$ in concentration 17.5, 35 (i.e. modern seawater) and 54 wt.\%o.

In conclusion, the fluid in CL-blue veins has a salinity of the order of seawater, the fluid in CL-brown veins is slightly less saline than seawater. The relative difference in the $\mathrm{T}_{\mathrm{mi}}$ of both fluids (Fig. 7) converts into a salinity difference of 18 wt.\%, roughly half of seawater salinity.

\subsection{4-Salinity signatures}


In order to interpret the difference in salinity between the CL-blue and CL-brown quartz (Fig. 7), one needs first to assess the heterogeneity in the pore fluids within sediments entering various modern subduction zones. The variations in salinity in pore water from incoming sediments in the Barbados (Shipboard Scientific Party, 1988), in Peru (Shipboard Scientific Party, 2003a; Shipboard Scientific Party, 2003b; Shipboard Scientific Party, 2003c) and in Nankai (Expedition 322 Scientists, 2010a; Expedition 322 Scientists, 2010b; Shipboard Scientific Party, 2001) are limited to at most 10\% with respect to seawater. The intrinsic variability of pore water in shallow, incoming sediments is therefore much smaller and cannot account for the differences in salinity in the fluid inclusions measured here ( $\sim 50 \%$ of seawater salinity).

Besides, fluid inclusion from fossil accretionary prisms such as the Franciscan complex in the U.S.A. (Dalla Torre et al., 1996; Sadofsky and Bebout, 2004) or the Alps (Mullis et al., 1994) show down to $\sim 5 \mathrm{kbars}$ and $300^{\circ} \mathrm{C}$ salinities similar or lower than seawater, similarly to the fluid inclusions analyzed here. Furthermore, seawater-like or less saline than seawater fluids can be found at larger depths, in low-temperature eclogites formed for $\mathrm{P} 10$ kbars in the Dominican Republic and in the Franciscan Complex (Giaramita and Sorensen, 1994). The only deep fluids much more saline than seawater were described in eclogites from the Alps (Philippot and Selverstone, 1991; Scambelluri and 
Philippot, 2004) for pressure conditions larger than 20 kbars. The mobility of such deep, very saline fluid is probably limited, as attested by oxygen isotopes (Scambelluri and Philippot, 2004), so that they are not relevant for the lower pressure conditions considered here. As a result, in the depth range of the Shimanto Belt, typical fluid salinity is similar to or lower than seawater.

In modern margins including the Costa Rica (Shipboard Scientific Party, 2003d), Barbados (Saffer and Tobin, 2011a) or Nankai margins (Kastner et al., 1993), fluids less saline than seawater have been commonly observed along permeable horizons focusing the fluid circulation. They are interpreted as reflecting the dilution of in-situ seawater by a less saline water reservoir (Kastner et al., 1991; Saffer and Tobin, 2011b), whose largest sources would be the smectite dehydration or the smectite to illite reaction (Kastner et al., 1991; Vrojlik, 1987), active in the range $\sim 50-150^{\circ} \mathrm{C}$ (Freed and Peacor, 1989; Kastner et al., 1991; Velde and Vasseur, 1992) or the saponite to chlorite reaction in altered oceanic crust, taking place in the range $150-250^{\circ} \mathrm{C}$ (Kameda et al., 2011b; Merriman and Frey, 1999). On the contrary to such dilution, the possible processes to increase the salinity of seawater are limited: the very large salinity (several times that of seawater) of all of the brines described at depths in different basins is typically associated with evaporites or evaporation (dissolution of evaporites, mixing with the 
connate water of evaporites, infiltration to depths of surface water affected by evaporation and solute concentration; (Egeberg and Aagaard, 1989; Hanor, 1993; Iampen and Rostron, 2000; Land and Prezbindowsky, 1981; Matray and Chery, 1998)). This is not possible in the present case, as no evaporites are described in the Shimanto Belt (Taira et al., 1988). Furthermore, limestones are virtually absent from the Shimanto Belt so that carbonate dissolution or precipitation, another possible diagenetic reaction that can alter the composition of pore water, has probably not affected much the composition of pore water.

To summarize, the study of paleo- and modern fluids in sediments shows that in accretionary prisms the evolution of the water trapped in sediment pores is toward lower salinity upon progressive burial, due to the release of water initially bound to minerals. This evolution is consistent with the lower-than-seawater salinity of the fluid interpreted as the "local" fluid, corresponding to the CL-brown quartz. In contrast, the "external" fluid associated with the CL-blue quartz is interpreted as a seawater-like fluid not affected by any significant dilution.

\subsection{5-Aluminum concentration and cathodoluminescence}

The other chemical signature coinciding with the two kinds of fluids and precipitated quartz is the concentration in aluminum measured by EPMA (Fig. 10). CL studies have 
shown that a bright blue CL color at $400 \mathrm{~nm}$ is characteristic of hydrothermal quartz, while metamorphic quartz usually has a red-brown CL color around 600nm (Götze et al., 2001). At an atomic scale, although it is still a point of debate (Lehmann et al., 2009), the luminescence center associated with the evanescent CL blue color could be the $\mathrm{Al}^{3+}$ structural defect replacing $\mathrm{Si}^{4+}$ in quartz lattice (Götze et al., 2001). Our study confirms the close correspondence between aluminum concentration and the evanescent blue CL color. The connection between $\mathrm{Al}$ concentrations in the crystals and in the fluid is much more difficult, as the process of incorporation of aluminum from the fluid into the quartz crystals as structural impurity is not well constrained and depends not only on the $\left[\mathrm{Al}^{3+}\right]$ in the fluid but also on the pressure, temperature and growth rate (Rumyantsev and Novozhilov, 1980; Tsinober and Kamentsev, 1964) as well as pH of the solution (Merino et al., 1989).

To interpret the different concentrations in aluminum of the two kinds of quartz in terms of sources of fluid is therefore difficult, as it depends not only on the original composition of the fluid but also on the extent of its re-equilibration with the host rock, Such re-equilibration is controlled by many different possible metamorphic reactions, some of them very sluggish given the low temperature $\left(\sim 250^{\circ} \mathrm{C}\right)$ that prevailed. Without further information on growth rate and $\mathrm{pH}$, one can simply note that the dominant 
reaction of clays at low grade, the smectite to illite transformation, produces silica, water and in turn consumes alumina (Hower et al., 1976; Kastner et al., 1991). Therefore, $\mathrm{Al}^{3+}$ concentrations in the two types of quartz are qualitatively in agreement with the salinity contrast; the fluid associated with CL-brown quartz, with a lower $\left[\mathrm{Al}^{3+}\right]$, possibly reflects the pore water dilution and the consumption of aluminum by in-situ clay reactions.

\subsection{6-Isotopic signature}

In-situ, $\delta^{18} \mathrm{O}$ analyses (Fig. 9) carried out over several samples show that CL-blue and CL-brown quartz have similar values within a given sample but vary between samples, within a range of +17 to $+20 \%$. Although we did not carry out analyses of host rock quartz, this range of variation is very similar to typical values of quartz in metapelites in the Kinki area of the Shimanto Belt (Masuda et al., 1992), in the Franciscan Complex (Sadofsky and Bebout, 2004), in the Alps (Hoernes and Friedrichsen, 1980; Mullis et al., 1994) or in the Ghost Rocks Formation from the Kodiak accretionary prism (Vrolijk, 1987). The similar isotopic compositions of quartz in host rock and veins and the variability of these compositions between the sampled localities is a common feature of buried metapelites (Bebout, 1991; Bebout, 1995; Mullis et al., 1994; Sadofsky and Bebout, 2001; Vrolijk, 1987) and is interpreted as reflecting rock-buffering due to a 
small water:rock ratio and a limited circulation of water, which was also reported in the Shimanto Belt (Lewis and Byrne, 2003). Our in-situ isotopic study confirms the control of host rock quartz on the $\delta^{18} \mathrm{O}$ of vein quartz and the impossibility of tracking external sources of fluids through their oxygen isotopic signature.

\subsection{7-Inconsistency between geochemical signatures}

There is a striking contrast between the salinity (and aluminum) signature, which is different in the two kinds of quartz and therefore not controlled by the host rock, and the oxygen isotopic signal, which is host rock buffered, irrespectively of the type of quartz considered. We propose that there are both a kinetic and a thermodynamic reason for the difference in behavior between salinity/aluminum concentration and $\delta^{18} \mathrm{O}$ signals.

At $250^{\circ} \mathrm{C}$, the quartz-fluid reequilibration in $\delta^{18} \mathrm{O}$ proceeds principally by dissolution-precipitation (Matsuhisa et al., 1978). Typical timescales of reequilibration predicted by dissolution precipitation, for grain size of 10 microns and fluid rock ratio of a few percent, is of the order of 1 year (Cole et al., 1983). Accordingly, in mélange rocks where intensive dissolution-precipitation of quartz is suggested by the density of quartz veins, isotopic equilibration is achieved rapidly. On the other hand, the reactions that may change the salinity are mostly dehydration reactions, which dilute the original 
seawater. These reactions have a much slower kinetics, as they proceed during temperature increase with increasing burial, which is a slower process. The same reason holds for the aluminum concentration in quartz: the uptake of aluminum depends on the fluid re-equilibration with the host rock, hence on the progress of metamorphic reactions. Most of these reactions, including the smectite to illite reaction, which consumes aluminum, proceed slowly, at the same pace as burial (Hyndman et al., 1997). For these reasons, the fluid complete re-equilibration is slow and the quartz grown in presence of the two fluids preserves distinct signatures in aluminum concentration.

The thermodynamic reason for the contrast between salinity and $\delta^{18} \mathrm{O}$ signals is the size of the reservoirs available for reequilibration. We assume that fluid reequilibrates isotopically with host rock quartz. The porosity (hence the water amount) is of the order of $3 \%$ in the Hyuga mélange rocks (Tsuji et al., 2006), hence the mass of the water reservoir is $\sim 30 \mathrm{~kg} / \mathrm{m}^{3}$ of rock. The rock weight proportion of quartz is of the order of $40 \%$ (Kameda et al., 2011a), so with a rock density of 2.7 and a weight proportion of oxygen in $\mathrm{SiO}_{2}$ of $\sim 0.5$, the stock of oxygen of the rock exchangeable with the fluid is $\sim 20$ times larger than the stock of oxygen in the fluid. Now, the capacity of the sediments to decrease the salinity of pore water is mainly controlled by the water contained in the smectite. The total amount of water bound to smectite can be estimated as $M_{w} \approx A \alpha$, 
where $A$ is the weight percent smectite in the bulk dry sediment and $\alpha$ the mass fraction of interlayer $\mathrm{H}_{2} \mathrm{O}$ in the hydrated smectite (Brown and Ransom, 1996). Considering, for the Nankai accretionary prism, the on-land sediments of Miura Peninsula, Japan, Kameda et al. (2010) used A as 0.26 and $\alpha$ as 0.2 (that is two layers of water in the interlayer space), which gives a mass proportion of $5 \mathrm{wt} \%$ of bound water (contained in interlayers in smectites) with respect to the weight of sediments without porosity, which converts into $\sim 12 \%$ volume, i.e. a size lower than or equivalent to the initial seawater contained in the pores. For a given proportion of pore water, the rock has therefore a much larger capacity to buffer the water $\delta^{18} \mathrm{O}$ than its salinity.

In summary, both because of reaction kinetics and buffering capacity, the salinity and aluminum concentration are much robust signatures of the fluid origin than oxygen isotopic composition.

\section{2-Models of fluid circulation within accretionary prisms}

From the discussion above, the source of salinity in the shallow $\left(\mathrm{T} \leq 300^{\circ} \mathrm{C}, \mathrm{P} \leq 5 \mathrm{kbars}\right)$ domain of accretionary prisms is probably seawater itself. The formation of CL-blue quartz at depth implies that a seawater-like fluid is able to be percolate without being affected by significant dilution. Two possible models are discussed in what follows. 6.2.1- Slow, downward flux of seawater-like fluid in the pores of subducting slab 
The first model to carry seawater down is its transport in the pores of subducting lithologies where dehydration reactions, hence dilution, is negligible. Considering incoming sediments in the Nankai Trough as a reference for subducted sediments, the lowest smectite absolute abundance is $10 \%$ in the most sand-rich lithologies (Steurer and Underwood, 2005). For a porosity of $20-30 \%$, the corresponding volume of fresh water produced by the smectite to $\rightarrow$ illite reaction is $15-30 \%$ of the pore volume (Saffer and McKiernan, 2009). So in sediments, even in the most unfavourable lithologies, the freshening of pore water is significant. The other large reservoir of pore water within the subducting slab is the extrusive pile constituting the upper levels of the oceanic crust, whose thickness is $\sim 500-1000 \mathrm{~m}$ and porosity is of the order of $5-10 \%$ (Carlson, 2010; Carlson and Herrick, 1990). As a result of this large porosity, the extrusive pile is affected by penetrative, low-temperature hydrothermal alteration, marked by the ubiquitous presence of saponite (Alt and et. al., 1996; Wilson and et. al., 2006). Saponite dehydrates in the range $150-250^{\circ} \mathrm{C}$ (Kameda et al., 2011b; Merriman and Frey, 1999), resulting in the freshening of pore water. Further down within the oceanic crust, the mineral assemblages do not include saponite, but the porosity drops to low values (Carlson, 2010; Carlson and Herrick, 1990), so that pore water does not constitute a significant reservoir of pore water. In summary, when the oceanic crust is sufficiently 
porous to carry a significant volume of pore water, it is also affected by hydrothermal alteration and contains a large proportion of phyllosilicates, which dehydrate upon burial and provide pure water. In other words, there is no large reservoir of pore water that could be preserved, during subduction, from significant dilution by dehydration reactions.

\subsection{2- Fast downward flux of sea water-like fluid as a result of earthquakes}

The other possible source of seawater-like fluids associated with the CL-blue quartz is therefore seawater itself or shallow pore water in sediments that have not been affected yet by a significant metamorphic production of pure water. Considering for example the smectite to illite reaction, the reservoir of seawater-like fluids is restricted to temperatures below $\sim 50^{\circ} \mathrm{C}$ (Freed and Peacor, 1989; Kastner et al., 1991; Velde and Vasseur, 1992), hence to depths below $\sim 2 \mathrm{~km}$.

Such a shallow origin for the seawater-like fluid implies its large-scale transport, down to the deep domains of the Shimanto accretionary prism (i.e. $10-15 \mathrm{~km}$ (Toriumi and Teruya, 1988)), without significant dilution. The absence of dilution implies that the downward flow of seawater-like fluid is (i) focused along permeable horizons and (ii) rapid with respect to the kinetics of pure water production by prograde reactions. In addition, such a downward flow is transient, as in the long-term the compaction of 
accreted sediments requires an upward expulsion of water (Le Pichon et al., 1991).

Earthquakes and the associated deformation and changes in stress are the best candidate to account for transient changes in fluid pressure and the onset of downward fluxes. Indeed, the study of the hydrological response to earthquakes by Muir-Wood and King (1993) showed that (i) the water volumes involved in post-seismic flow may be large, i.e. orders of magnitude larger than flows predicted by steady-state compaction of compacting sediments (Le Pichon et al., 1993; Le Pichon et al., 1991) and (ii) the depth range of the water flow is of the order of $5 \mathrm{~km}$. Chemical anomalies in ground water following earthquakes (Sato and Takahashi, 1997; Tsuneishi and Nakamura, 1970) also suggest a water flow over several $\mathrm{km}$ of depth, from the zone of melting/pseudotachylite generation up to the surface (Famin et al., 2008). Finally, the time-scale of post-seismic flow is a couple of months, i.e. sufficiently rapid to avoid significant dilution/mixing of the channelized, moving fluid with surrounding, in-situ fluid.

Beyond the qualitative agreement between the features of observed postseismic water flows and the downward fluid circulations proposed here, the $2011 \mathrm{Mw}=9.0$ Tohoku-Oki earthquake offers the opportunity to estimate pore pressure transients related to mega-earthquakes and to assess whether they are large enough to trigger the onset of a downward flow of water. The location of the zone of maximum of slip near the trench 
(see the review in Tajima et al. (2013)) implies horizontal extension landward of it. More precisely, from measured coseismic displacements of seafloor instruments, the horizontal extension is $\sim 1-210^{-3}$ in a domain $\sim 40 \mathrm{~km}$ away from the trench (Ito et al., 2011). In contrast, most if not all of the vertical displacement may be accounted for by the rigid-body translation of the whole prism and vertical deformation is negligible. If, in addition, one supposes that deformation in the direction parallel to trench is also negligible, then one can consider that the $20 \mathrm{~km}$-large and $\sim 8 \mathrm{~km}$-deep prism portion concentrating the horizontal extension (between GJT3 and TJT1 sites of Ito et al. (2011)) was affected by an expansion of the order of $1-210^{-3}$.

This expansion is accommodated for in part by the solid grains and in part by the water filling the pores, with a response depending on the poroelastic properties of the rocks. Poroelastic properties strongly vary with depth and porosity and for subduction zones, only relatively shallow modern sediments $(<1500$ meters below seafloor $)$ were experimentally tested. For deeper sediments, we considered experimental data acquired either on sandstones, for which the largest dataset is available, or shales (see Appendix). As a result, the decrease in pore pressure associated with a bulk expansion of 1 to $210^{-3}$ is $\sim 6-12 \mathrm{MPa}$ for high-porosity (30 to $40 \%$ ) and $\sim 20-40 \mathrm{MPa}$ for low-porosity $(<10 \%)$ material. 
A drop of 10-40 $\mathrm{MPa}$ in fluid pressure may have large consequences on the fluid circulations, depending on the initial pore fluid pressure gradient. Fitting the NE Japan wedge geometry with their set of internal and basal friction, Davis et al. (1983) estimated, though with a large uncertainty, the fluid pressure ratio $\lambda=\frac{\mathrm{P}_{\mathrm{F}}-\rho_{\mathrm{w}} \mathrm{gD}}{\left|\sigma_{\mathrm{z}}\right|-\rho_{\mathrm{w}} \mathrm{gD}}$ as 0.5 , with $\rho_{\mathrm{w}} \mathrm{gD}$ the pressure on the seafloor, $\mathrm{P}_{\mathrm{F}}$ the pore fluid pressure and $\left|\sigma_{z}\right|$ the vertical, bulk stress. For reference, $\lambda$ can vary between 0.4 (hydrostatic pore fluid pressure, calculated for $\rho_{\text {bulk }}=2.5 \mathrm{~g} \mathrm{~cm}^{-3}$ ) and 1 (lithostatic pore fluid pressure). This relatively low fluid pressure gradient is further supported by the fact that the input of fluid, hence the sources of fluid overpressure, are much more limited in non-accretionary margins, such as NE Japan (Von Huene and Lallemand, 1990), than in accretionary ones. Whether the case study of NE Japan applies to the paleo-margin of the Shimanto is more difficult to evaluate. The modern Nankai margin is indeed an accreting margin, but the geometry and the dynamics of the paleo-margin of the Shimanto, at the time when the quartz veins formed, is not known.

Considering 0.5 as an approximation of fluid pressure ratio yields an excess fluid pressure (with respect to hydrostatic state), in the pre-seismic state, of $12 \mathrm{MPa}$ at $5 \mathrm{~km}$ depth and $25 \mathrm{MPa}$ at $10 \mathrm{~km}$ depth. Comparing these figures with the amplitude of fluid pressure decrease related to earthquake deformation (10-40 $\mathrm{MPa}$ ) shows that such 
decrease is able to generate fluid pressure below hydrostatic and to trigger a top-down flow, at least in the shallow (down to $10 \mathrm{~km}$ depth) domain of accretionary prism. Note that a drop of pore fluid pressure below hydrostatic pressure does not imply a switch in earthquake focal mechanisms to tensional; if the pore pressure drop and the stress drop are correlated, the final (=post-earthquake) states of stress and pore pressure depends also on the initial (=pre-earthquake) states, which are uncorrelated.

A conceptual sketch of earthquake-related fluid circulation is proposed in Fig. 12. In the pre-seismic state, fluid pressure is everywhere above hydrostatic and fluid flow upward-directed, either in the bulk or focused along permeable horizon. Co-seismic strain results in bulk rock dilation and pore fluid pressure decrease in the outer domain of the accretionary prism affected by extension. In cases where pre-seismic pore fluid pressure was only slightly above hydrostatic, co-seismic pore pressure drop reverses the fluid flow and triggers the downward percolation to depth of seawater or pore fluid of shallow sediments.

\section{7-Conclusion}

The Hyuga and Morotsuka Groups, in the inner domain of the Shimanto Belt, provide fossil exposures of the deep domains of accretionary prisms. Our cathodoluminescence and microstructural study of samples from these units unraveled the existence of two 
distinct fluids, as well as the cyclic pattern of their circulations. In the usual, closed state of the system, a "local", low $\left[\mathrm{Al}^{3+}\right]$ and low-salinity fluid is wetting the rock and precipitates CL-brown quartz in micro-veins or assists ductile recrystallization. Periodically, macro-fracturing triggers the opening of the system and the transient percolation of an "external" fluid, which precipitates CL-blue quartz in macro-veins. Permeability drops as a result of vein filling, and the "external" fluid equilibrates progressively with the host rock towards the composition of the "local" fluid.

The best candidate for the reservoir of the "external" fluid is seawater or the pore water in shallow ( $<1-2 \mathrm{~km}$ below seafloor) sediments, which implies its percolation down to the deep ( 10km depth) domains of accretionary prism. The most appropriate process to trigger a transient, top-down flow is subduction mega-earthquakes and the resulting strain and pore fluid pressure changes, which triggers large displacement of water over large distance/depth range and over short times. Such a rapid displacement of water explains the preservation of the salinity of the "external" water during its downward percolation.

\section{Appendix}

In the following, we assess the variation in pore pressure $\delta P_{p}$ resulting for a given bulk 
rock strain $\varepsilon_{b}$. For the simplest assumption of isotropic material and in the undrained case where the fluid cannot move relatively to the rock framework, $\varepsilon_{b}$ and $\delta P_{p}$ are related through (Jaeger et al., 2007):

$$
\varepsilon_{b}=\frac{1}{K}\left(\frac{1}{B}-\alpha\right) \delta P_{p}
$$

where $K$ is the drained bulk incompressibility $\left(\frac{1}{K}=-\frac{1}{V}\left(\frac{\partial V}{\partial P_{c}}\right)_{P_{p}}\right)$, B the Skempton coefficient $\left(B=\left(\frac{\partial P_{p}}{\partial P_{c}}\right)_{\text {undrained }}\right), \alpha$ the Biot coefficient $\left(\alpha=1-\frac{K}{K_{m}}\right), P_{c}$ the confining pressure and $K_{m}$ the incompressibility modulus of the porous rock matrix.

Ideally, $\delta P_{p}$ can be directly computed if $K, B$ and $\alpha$ have been experimentally measured. This was the case only in Song and Renner (2008) or Suarez-Rivera and Fjaer (2013), for sandstones with a porosity between 3 and 10\% and for shales with a porosity between 4 and $8 \%$, respectively. These stiff and low-porosity rocks are considered as equivalent to the deep domains of accretionary prisms. In both studies, coefficients vary with applied effective pressure, so we made the calculations with $P_{e f f}$ in the range 40 to $50 \mathrm{MPa}$. For these conditions, the variation in pore pressure associated with a bulk strain of $0.1 \%$ is in the range $\sim 10-20 \mathrm{MPa}$ for sandstones and $\sim 2.5-5 \mathrm{MPa}$ for shales.

When only a single poroelastic coefficient is provided, one needs additional assumption to derive $\delta P_{p}$, for example the matrix incompressibility $K_{m}$. We consider $K_{m} \sim 38 \mathrm{GPa}$ for 
a quartz-rich matrix (Kuster and Toksoz, 1974; Levien et al., 1980), $K_{m} \sim 25 \mathrm{GPa}$ for a clay rich matrix (Alberto Ortega et al., 2007) and take in addition an average fluid incompressibility as $K_{f} \sim 2.5 \mathrm{GPa}$ (Knauss, 2005). With these assumptions and the Skempton coefficients (Blocher et al., 2007; Blocher et al., 2009; Lockner and Stanchits, 2002), for sandstones equivalent to deep domains of accretionary prisms, the variation in pore pressure associated with a bulk strain of $0.1 \%$ is in the range $\sim 8-12 \mathrm{MPa}$, i.e. consistent with the calculations based on the experiments of Song and Renner (2008).

For clay-rich, shallow material directly collected in modern marine sediments, with a porosity of $30 \%$ (Karig and Ask, 2003) to 40\% (Bourlange et al., 2004), we used the experimentally-determined bulk compressibility $K$ and the $K_{m}$ corresponding to clays. In such a case, the variation in pore pressure associated with a bulk strain of $0.1 \%$ is of the order of $\sim 6 \mathrm{MPa}$.

\section{Acknowledgements}

This work has received funding from (i) the European Research Council (ERC) under the seventh Framework Programme of the European Union (ERC Advanced Grant, grant agreement No 290864, RHEOLITH) and (ii) the Labex VOLTAIRE 
(ANR-10-LABX-100-01). The authors thank the two reviewers (Donald Fisher and an anonymous reviewer) and the editor for their very detailed and constructive reviews. Thin and thick sections were prepared by Gabriel Badin and Sylvain Janiec. We thank Claire Rollion-Bard, Andrei Gurenko and Etienne Deloule at CRPG for the ion microprobe analyses.

\section{Figures}

Figure 1: Map of the Shimanto Belt, simplified from Murata (1997), showing the localization of analyzed samples. Most samples were collected in the Hyuga tectonic mélange, on top of the Hyuga Group, while two samples (referred to with italic labels) belong to the higher-grade foliated formation at the base of the Morotsuka Group.

Figure 2: Macroscopic occurrences of quartz veins. A) Fracturing and quartz veining of sandstone layers perpendicular to extension in coherent domains of Hyuga. In this example, the timing of veining is unclear. B) Veining (white areas) of sandstones blocks (grey areas) in strongly deformed domains of the Hyuga mélange. Early-stage veins predating the ductile deformation are transposed parallel to the foliation (blue 
triangles) and sheared by top-to-the-SE shear zones (green triangles). C) Veins postdating the foliation-forming metamorphic stage in Morotsuka. In each picture, bedding/foliation is indicated by $\mathrm{S}_{0} / \mathrm{S}_{1}$.

Figure 3: CL-blue quartz veins cutting across the foliation. A) Three generations of veins in sample HN84, with the oldest one (V1) transposed towards foliation and the following ones (V2 and V3) at higher angle to the foliation. Crosscutting relationships are elucidated by the colors of the veins: The older the veins, the smaller the density of the CL-blue patches. B) Most of the CL-blue veins that can be observed postdate quartz domains where the grains are elongated parallel to the foliation. Note the large difference in fluid inclusion density between the CL-blue vein, poor in inclusions (green triangles) and the host grains, clouded with inclusions (sample HN51). A-B: Cathodoluminescence, A'-B': Optical microscope pictures.

Figure 4: Microfracturing and replacement of CL-blue quartz by CL-brown one by dissolution-precipitation. A) The macro-vein orientated N-S in the figure, of CL-blue color and with a low density of fluid inclusions, is crosscut by numerous micro-veins (typical examples shown with dashed lines) orientated roughly perpendicular to the 
macro-vein. In these micro-veins, CL-brown quartz is precipitated along with trails of fluid inclusions. The original CL-blue quartz is only preserved in disseminated patches (sample HN66). B) The quartz domain labeled B-B' is precipitated on the border of and in a vein cutting across an older quartz domain labeled A. Each quartz domain, originally CL-blue, is progressively replaced by CL-brown quartz precipitating along micro-veins (an example shown as dashed line) along with fluid inclusion trails. The older the quartz domain, the larger the progress of such replacement, so that domain in domain A CL-blue quartz is much less preserved than in domain B (sample HN67). Left: Cathodoluminescence - Right: Optical microscope pictures.

Figure 5: Effect of ductile deformation on CL-blue/brown luminescence. Panels A, A', A" and B show a partially recrystallized sample (HN77 from Hyuga mélange), while panels C , C' and C" show a much more recrystallized sample (HN243 from foliated Morotsuka). A, A', A"): A former quartz vein, constituted of domains 1 to 3 , is heterogeneously deformed and recrystallized. Domains 1 and 2, with a patchy and bluish CL-shade, are constituted of parent grains (with elongated/equant shape for domain 1/2, see A"), containing a large density of fluid inclusions (A'). B): Close-up view of domain 3 (reference rectangle shown in A"), located in the neck of the deformed vein. Serrated 
grain boundaries and the relative absence of fluid inclusions attest of the intensity of deformation and recrystallization. C, C' and C') In a more strongly deformed sample, a quartz vein is shortened, folded and transposed parallel to the foliation. The quartz grains within the veins are completely recrystallized and develop a homogeneous, brownish CL color. A-C: Cathodoluminescence, A'-A"-B-C': optical microscope polarized light without (A', C') and with crossed nicols (A", B and C").

Figure 6: Patterns of growth and fracturing/recrystallization revealed by cathodoluminescence. A) Five successive growth rims can be observed in CL. In addition, in stages 4 and 5, quartz precipitates along a vein with a rim of CL-brown quartz ("V4") and a core of CL-blue quartz ("V5"). CL-blue quartz domains (1 and 3) are not homogeneous but contain patches of CL-blue quartz surrounded by CL-brown quartz (sample HN46). B) Growth rims, alternatively CL-blue (1 and 3) and CL-brown (2), crosscut by veins, either CL-blue $\left(\mathrm{V}_{\mathrm{bl}}\right)$ or CL-brown $\left(\mathrm{V}_{\mathrm{br}}\right)$. The veins, irrespectively of their CL color, have a lower density in fluid inclusions than host quartz. Among the growth rims, CL-blue quartz has a larger density in fluid inclusions than the CL-brown one (sample Kondo-NB26-23). C) Alternating CL-blue and CL-brown quartz growth rims (1 to 7). Domains 1 to 5 follow crystallographic faces, while domain 7 cuts across 
former limits (white arrow), hence results from precipitation after a stage of dissolution.

CL-brown quartz is the last infill of the vein, as it wraps around idiomorphic, CL-blue quartz. CL-brown quartz, in addition to grain growth rims, precipitates also in micro-veins cutting across former, CL-blue quartz domains. Note also that the pattern of fluid inclusion distribution does not exactly match the blue/brown CL color distribution (sample HN48). Left: Cathodoluminescence, right: optical microscope.

Figure 7: A) Temperatures of melting of the last crystal of ice $\left(\mathrm{T}_{\mathrm{mi}}\right)$, in fluid inclusions from six microstructural sites out of five samples. Blue/brown symbol colors refer to the CL color of the quartz hosting the fluid inclusions. Three reference $\mathrm{T}_{\mathrm{mi}}$ are shown for mixtures of $\mathrm{H}_{2} \mathrm{O}+1.5 m_{\mathrm{CH}_{4}}$ and dissolved $\mathrm{NaCl}$ in concentration 17.5, 35 (i.e. modern seawater) and 55 wt.\%o (dashed lines with labels a, b, c, respectively). The vertical gray rectangle correspond to the a mixture of $\mathrm{H}_{2} \mathrm{O}+1.5 m_{\mathrm{CH}_{4}}$ and dissolved $\mathrm{NaCl}$ in concentration 37-39 wt.\%, a salinity relevant for seawater of Early Miocene (Hay et al., 2006). The uncertainty on each $\mathrm{T}_{\mathrm{mi}}$ measurement on the cooling stage is estimated as $\sim 0.8^{\circ} \mathrm{C}$ and is shown for as a horizontal error bar on the $\mathrm{T}_{\mathrm{mi}}$ peaks for the two populations of fluid inclusions. B) Homogeneization temperatures for fluid inclusions from six microstructural sites out of four samples, with the same color references as in A). 
Figure 8: Comparison of in $^{-}$situ oxygen isotopic value ( $\delta^{18} \mathrm{O}$ in \%o with respect to SMOW) of CL-blue and CL-brown quartz obtained by ion microprobe. In sample HN198 (A-A'), the elongated CL-brown quartz grains are crosscut by later-stage veins made of CL-blue quartz. In sample Kondo-NB25-46 (C-C'), CL-blue quartz veins cut across a large grain showing growth rims alternatively CL-blue and CL-brown. The corresponding plots (B and $\mathrm{D}$, respectively) of $\delta^{18} \mathrm{O}$ of spots indicated in the photomicrographs as ellipses do not show in either case any difference between CL-blue and CL-brown quartz. Uncertainty $(1 \sigma)$ is shown on the right of each plot. A, C) Cathodoluminescence, (A', C') optical microscope.

Figure 9: $\mathrm{In}^{-}{ }^{\mathrm{situ}} \delta^{18} \mathrm{O}$ (in \%o with respect to SMOW) of CL-blue and CL-brown quartz in all samples analyzed. Variations between samples are larger than variations within a given sample between CL-blue and CL-brown quartz, which are statistically not different.

Figure 10: A) Cathodoluminescence image and B) EPMA semi quantitative analysis of $\mathrm{Al}$ content (right-scale in counts per second). The quartz domain is surrounded by a 
white line in A). CL-blue quartz has higher aluminium content than CL-brown quartz.

Figure 11: Sketch of cyclic formation of CL-blue and CL-brown quartz. Episodic rock fracturing enables the infiltration of external, saline fluid, leading to the precipitation of CL-blue quartz as filling of macro-veins. After closure of the veins and decrease in permeability, the fluid is diluted by dehydration or metamorphic reactions of clay minerals. The CL-brown quartz, corresponding to the diluted fluid, precipitates in micro-veins or as growth rims. In parallel, ductile deformation, assisted by this local fluid, results locally in recrystallizing CL-brown quartz grains. Then another event of macrofracturing and external influx of saline fluid occurs, resuming the cycle.

Figure 12: Evolution of the fluid pressure and flow during a seismic cycle. Before the earthquake, the fluid pressure is slightly over the hydrostatic gradient and all fluid flow, either distributed in the bulk or focused along permeable horizons such as faults or décollement, is directed upward. After the earthquake, the poro-elastic dilation of a large domain of the accretionary prism results in decreasing the fluid pressure below the hydrostatic value. In such case, the fluid pressure gradient generates a top-down circulation of fluid, mostly originated from the seawater or the pore water of shallow 
and permeable sediments. As a consequence, a sedimentary rock in a structural position similar to the Shimanto natural samples studied here (red rectangle) records repeated events of shallow, saline water percolating to the depth and precipitating quartz veins.

\section{References}

Alberto Ortega, J., Ulm, F.-J. and Abousleiman, Y., 2007. The effect of the nanogranular nature of shale on their poroelastic behavior. Acta Geotechnica, 2: 155-182.

Alt, J.C. and et. al., 1996. Hydrothermal alteration of a section of upper oceanic crust in the eastern equatorial Pacific: a synthesis of results from site 504 (DSDP legs 69, 70 and 83 and ODP legs 111, 137, 140 and 148). In: J.C. Alt, H. Kinoshita, L.B. Stokking and P.J. Michael (Editors), Proc. ODP, Sci. Res., vol. 148, pp. 417-434.

Baldwin, B. and Butler, C.O., 1985. Compaction curves. AAPG Bull., 69: 622-626.

Bebout, G.E., 1991. Field-based evidence for devolitization in subduction zones: Implications for arc magmatism. Science, 251(4992): 413-416.

Bebout, G.E., 1995. The impact of subduction-zone metamorphism on mantle-ocean chemical cycling. Chem. Geol., 126: 191-218.

Bekins, B.A. and Dreiss, S.J., 1992. A simplified analysis of parameters controlling dewatering in accretionary prisms. Earth Planet. Sci. Lett., 109: 275-287.

Blocher, G., Zimmermann, G., McDermott, C. and Huenges, E., 2007. Investigation of the undrained poroelastic response of sandstones to confining pressure via laboratory experiment, numerical simulation and analytical calculation. In: C. David and L. 
Ravalec-Dupin (Editors), Rock physics and geomechanics in the study of reservoirs and repositories. Geological Society of London, Special Publications vol. 284, pp. 71-87.

Blocher, G., Zimmermann, G. and Milsch, H., 2009. Impact of poroelastic response of sandstones on geothermal power production. Pure Appl. Geophys., 166: 1107-1123.

Bourlange, S., Jouniaux, L. and Henry, P., 2004. Data report: Permeability, compressibility, and friction coefficient measurements under confining pressure and strain, Leg 190, Nankai Trough. In: H. Mikada et al. (Editors), Proc. ODP, Sci. Results, 190/196, pp. 1-16. doi:10.2973/odp.proc.sr.190196.215.2004.

Bray, C.J. and Karig, D.E., 1985. Porosity of sediments in accretionary prisms and some implications for dewatering processes. J. Geophys. Res., 90(B1): 768-778.

Brown, K.M. and Ransom, B., 1996. Porosity corrections for smectite-rich sediments: Impact on studies of compaction, fluid generation, and tectonic history. Geology, 24(9): 843-846.

Carlson, R.L., 2010. How crack porosity and shape control seismic velocities in the upper oceanic crust: Modeling downhole logs from Holes 504B and 1256D. Geochem. Geophys. Geosystems, 11(Q04007): 1-15.

Carlson, R.L. and Herrick, C.N., 1990. Densities and porosities in the oceanic crust and their variations with depth and age. J. Geophys. Res., 95(B6): 9153-9170.

Chan, L.H. and Kastner, M., 2000. Lithium isotopic compositions of pore fluids and sediments in the Costa Rica subduction zone: implications for fluid processes and sediment contribution to the arc volcanoes. Earth Planet. Sci. Lett., 183: 275-290.

Cole, D.R., Ohmoto, H. and Lasaga, A.C., 1983. Isotopic exchange in mineral-fluid systems. I. Theoretical evaluation of oxygen isotopic exchange accompanying surface reactions and diffusion. Geochim. Cosmochim. Ac., 47: 1681-1693.

Dahlen, F.A., 1984. Noncohesive Critical Coulomb Wedges - An Exact Solution. J. Geoph. Res., 89(B12): 125-133.

Dahlen, F.A., 1990. Critical taper model of fold-and-thrust belts and accretionary wedges. Annual Review of Earth And Planetary Sciences, 18: 55-99.

Dalla Torre, M. et al., 1996. Very low-temperature metamorphism of shales from the Diablo Range, Franciscan Complex, California: New constraints on the exhumation path. GSA Bull., 108(5): 578-601.

Davis, D., Suppe, J. and Dahlen, F.A., 1983. Mechanics of fold-and-thrust belts and accretionary wedges. Journal of Geophysical Research, 88(NB2): 1153-1172.

Duan, Z. and Mao, S., 2006. A thermodynamic model for calculating methane solubility, density and gas phase composition of methane-bearing aqueous fluids from 273 to 
523K and 1 to 2000 bars. Geochim. Cosmochim. Ac., 70: 3369-3386.

Duan, Z., Moller, N. and Weare, J.H., 1992. An equation of state for the $\mathrm{CH}_{4}-\mathrm{CO}_{2}-\mathrm{H}_{2} \mathrm{O}$ system: I. Pure systems from 0 to $1000^{\circ} \mathrm{C}$ and 0 to 8000 bar. Geochim. Cosmochim. Ac., 56: 2605-2617.

Egeberg, P. and Aagaard, P., 1989. Origin and evolution of formation waters from oil fields on the Norwegian shelf. Applied Geochemistry, 4: 131-142.

El Mekki-Azouzi, M., 2010. Etude experimentale de l'eau et des solutions aqueuses métastables - implications pour le milieu naturel, Université d'Orléans, Orléans, 259 pp.

Expedition 322 Scientists, 2010a. Site C0011. In: S. Saito, M. Underwood, Y. Kubo and The Expedition 322 Scientists (Editors), Proc. IODP, 322. Integrated Ocean Drilling Program Management International Inc., Tokyo.

Expedition 322 Scientists, 2010b. Site C0012. In: S. Saito, M. Underwood, Y. Kubo and The Expedition 322 Scientists (Editors), Proc. IODP, 322. Integrated Ocean Drilling Program Management International Inc., Tokyo.

Faccenna, C., Becker, T.W., Lallemand, S. and Steinberger, B., 2012. On the role of slab pull in the Cenozoic motion of the Pacific plate. Geophys. Res. Lett., 39(L03305): 1-6.

Famin, V., Nakashima, S., Boullier, A.M., Fujimoto, K. and Hirono, T., 2008. Earthquakes produce carbon dioxide in crustal faults. Earth Planet. Sci. Lett., 265: 487-497.

Fisher, D.M. and Brantley, S.L., 2014. The role of silica redistribution in the evolution of slip instabilities along subduction interfaces: Constraints from the Kodiak accretionary complex, Alaska. J. Struct. Geol., 69B: 395-414.

Fisher, D.M., Brantley, S.L., Everett, M. and Dzonik, J., 1995. Cyclic fluid flow through a regionally extensive fracture network within the Kodiak accretionary prism. J. Geophys. Res., 100(B7): 12,881-12,894.

Freed, R.L. and Peacor, D.R., 1989. Variability in temperature of the smectite/illite reaction in Gulf Coast sediments. Clay Miner., 24: 171-180.

Götze, J., Plötze, M. and Habermann, D., 2001. Origin, spectral characteristics and practical applications of the cathodoluminescence (CL) of quartz - a review. Mineralogy and Petrology, 71: 225-250.

Giaramita, M.J. and Sorensen, S.S., 1994. Primary fluids in low-temperature eclogites: evidence from two subduction complexes (Dominican Republic, and California, USA). Contrib. Mineral. Petrol., 117: 279-292.

Gonfiantini, R., Stichler, W. and Rozanski, K., 1995. Standards and intercomparison materials distributed by the International Atomic Energy Agency for stable isotope measurements. IAEA-TECDOC-825: 13-29. 
Hanor, J.S., 1993. Physical and chemical controls on the composition of waters in sedimentary basins. Mar. Petrol. Geol., 11(1): 31-45.

Hara, H. and Kimura, K., 2008. Metamorphic cooling history of the Shimanto accretionary complex, Kyushu, southwest Japan: Implications for the timing of out-of-sequence thrusting. Island Arc, 17: 546-559.

Hay, W.H. et al., 2006. Evaporites and the salinity of the ocean during the Phanerozoic: Implications for climate, ocean circulation and life. Palaeogeography, Palaeoclimatology, Palaeoecology, 240: 3-46.

Henry, P. and Bourlange, S., 2004. Smectite and fluid budget at Nankai ODP sites derived from cation exchange capacity. Earth Planet. Sci. Lett., 219: 129-145.

Henry, P. et al., 1992. Interpretation of temperature measurements from the Kaiko-Nankai cruise: Modeling of fluid flow in clam colonies. Earth Planet. Sci. Lett., 109: 355-371.

Hoernes, S. and Friedrichsen, H., 1980. Oxygen and hydrogen isotopic composition of alpine and pre-alpine minerals of the Swiss Central Alps. Contrib. Mineral. Petrol., 72: 19-32.

Horne, R.A., 1969. Marine Chemistry. John Wiley \& Sons, New York, 568 pp.

Hower, J., Eslinger, E.V., Hower, M.E. and Perry, E.A., 1976. Mechanism of burial metamorphism of argillaceous sediment: 1 . Mineralogical and chemical evidence. GSA Bull., 87: 725-737.

Hyndman, R.D., Yamano, M. and Oleskevich, D.A., 1997. The seismogenic zone of subduction thrust faults. The Island Arc, 6: 244-260.

Iampen, H.T. and Rostron, B.J., 2000. Hydrogeochemistry of pre-Mississippian brines, Williston Basin, Canada-USA. Journal of Geochemical Exploration, 69-70: 29-35.

Imai, I., Teraoka, Y. and Okumura, K., 1971. Geologic structure and metamorphic zonation of the northeastern part of the Shimanto terrane in Kyushu, Japan. J. Geol. Soc. Jap., 77: 207-220 (in japanese with english abstract).

Ito, Y. et al., 2011. Frontal wedge deformation near the source region of the 2011 Tohoku -

Oki earthquake. Geophys. Res. Lett., 38(L00G05).

Jaeger, J.C., Cook, N.G.W. and Zimmerman, R.W., 2007. Fundamentals of rock mechanics. Blackwell Publishing Ltd, Malden, USA, 475 pp.

Kameda, J., Raimbourg, H., Kogure, T. and Kimura, G., 2011a. Low-grade metamorphism around the down-dip limit of seismogenic subduction zones: Example from an ancient accretionary complex in the Shimanto Belt, Japan. Tectonophysics, 502: 383-392.

Kameda, J. et al., 2011b. A new source of water in seismogenic subduction zones. Geophys. Res. Lett., 38(L22306): 1-5. 
Kameda, J., Yamamoto, Y. and Kimura, G., 2010. Smectite swelling in the Miura-Boso accretionary prism: Possible cause for incipient décollement zone formation. Tectonophysics, 494: 75-84.

Karig, D.E. and Ask, M.V.S., 2003. Geological perspectives on consolidation of clay-rich marine sediments. J. Geophys. Res., B4: doi:10.1029/2001JB000652.

Kastner, M., Elderfield, H., Jenkins, W.J., Gieskes, J.M. and Gamo, T., 1993. Geochemical and isotopic evidence for fluid flow in the western Nankai subduction zone, Japan. In: I.A. Hill, A. Taira and J.V. Firth (Editors), Proc. ODP, Sci. Results, 131, pp. 397-413.

Kastner, M., Elderfield, H. and Martin, J.B., 1991. Fluids in convergent margins: What do we know about their composition, origin, role in diagenesis and importance for oceanic chemical fluxes? Phil. Trans. R. Soc. Lond., 335(1638): 243-259.

Knauss, J.A., 2005. Introduction to physical oceanography. Waveland Press, Long Grove, Ill., $320 \mathrm{pp}$.

Kominz, M.A. and Pekar, S.F., 2001. Oligocene eustasy from two-dimensional sequence stratigraphic backstripping. GSA Bull., 113(3): 291-304.

Kondo, H. et al., 2005. Deformation and fluid flow of a major out-of-sequence thrust located at seismogenic depth in an accretionary complex: Nobeoka Thrust in the Shimanto Belt, Kyushu, Japan. Tectonics, 24(TC6008).

Kuster, G.T. and Toksoz, M.N., 1974. Velocity and attenuation of seismic waves in two-phase media: Part I. Theoretical formulations. Geophysics, 39(5): 587-606.

Land, L.S. and Prezbindowsky, D.R., 1981. The origin and evolution of saline formation water, Lower Cretaceous carbonates, south-central Texas, U.S.A. Journal of Hydrology, 54: 51-74.

Le Pichon, X., Henry, P. and Lallemant, S., 1990. Water flow in the Barbados accretionary complex. J. Geophys. Res., 95(B6): 8945-8967.

Le Pichon, X., Henry, P. and Lallemant, S., 1993. Accretion and erosion in subduction zones: The role of fluids. Annu. Rev. Earth Pl. Sc., 21: 307-331.

Le Pichon, X., Henry, P. and The Kaiko-Nankai Scientific Crew, 1991. Budgets in accretionary wedges: A comparison. Philosophical Transactions: Physical Sciences an Engineering, 335(1635): 315-330.

Lehmann, K., Berger, A., Gotte, T., Ramseyer, K. and Wiedenbeck, M., 2009. Growth related zonations in authigenic and hydrothermal quartz characterized by SIMS-, EPMA-, SEM-CL- and SEM-CC-imaging. Mineral. Mag., 73(4): 633-643.

Levien, L., Prewitt, C.T. and Weidner, D.J., 1980. Structure and elastic properties of quartz at pressure. Am. Mineral., 65: 920-930. 
Lewis, J.C. and Byrne, T.B., 2003. History of metamorphic fluids along outcrop-scale faults in a Paleogene accretionary prism, SW Japan: Implications for prism-scale hydrology. G-cubed, 4(9): 1-10.

Lockner, D.A. and Stanchits, S.A., 2002. Undrained poroelastic response of sandstones to deviatoric stress change. J. Geophys. Res., 107(B12).

Müller, R.D., Sdrolias, M., Gaina, C., Steinberger, B. and Heine, C., 2008. Long-term sea-level fluctuations driven by ocean basin dynamics. Science, 319(1357): 1-7.

Mao, S. and Duan, Z., 2008. The P,V,T,x properties of binary aqueous chloride solutions up to $\mathrm{T}=573 \mathrm{~K}$ and $100 \mathrm{MPa}$. J. Chem. Thermodynamics, 40: 1046-1063.

Marin, J., Chaussidon, M. and Robert, F., 2010. Microscale oxygen isotope variations in 1.9 Ga Gunflint cherts: Assessments of diagenesis effects and implications for oceanic paleotemperature reconstructions. Geochim. Cosmochim. Ac., 74: 116-130.

Masuda, H., Kusakabe, M. and Sakai, H., 1992. Hydrogen and oxygen isotope ratios of shales and characteristics of formation waters in sedimentary complexes accreted at different times, Kinki district, southwest Japan. Geochim. Cosmochim. Ac., 56: 3505-3511.

Matray, J. and Chery, L., 1998. Origin and age of deep waters of the Paris Basin. In: C. Causse and F. Gasse (Editors), Hydrologie and geochimie isotopique. ORSTOM, Paris.

Matsuhisa, Y., Goldsmith, J.R. and Clayton, R.N., 1978. Mechanisms of hydrothermal crystallization of quartz at $250^{\circ} \mathrm{C}$ and 15 kbar. Geochim. Cosmochim. Ac., 42: 173-182.

Merino, E., Harvey, C. and Murray, H.H., 1989. Aqueous-chemical control of the tetrehedral-aluminum content of quartz, halloysite, and other low-temperature silicates. Clays Clay Miner., 37(2): 135-142.

Merriman, R. and Frey, M., 1999. Patterns of very low-grade metamorphism in metapelitic rocks. In: M. Frey and R. Merriman (Editors), Low-grade metamorphism. Blackwell Science, pp. 61-107.

Moore, J.C. and Saffer, D., 2001. Updip limit of the seismogenic zone beneath the accretionary prism of southwest Japan: An effect of diagenetic to low-grade metamorphic processes and increasing effective stress. Geology, 29(2): 183-186.

Morris, J.D. and Villinger, H.W., 2006. Leg 205 synthesis: subduction fluxes and fluid flow across the Costa Rica convergent margin. In: J.D. Morris, H.W. Villinger and A. Klaus (Editors), Proc. ODP, Sci. Rpts, vol. 205, pp. doi:10.2973/odp.proc.sr.205.2006.

Muir-Wood, R. and King, G.C.P., 1993. Hydrological signatures of earthquake strain. J. Geophys. Res., 98(B12): 22,035-22,068. 
Mukoyoshi, H. et al., 2009. Style of fluid flow and deformation in and around an ancient out-of-sequence thrust: An example from the Nobeoka Tectonic Line ine the Shimanto accretionary complex, southwest Japan. Island Arc, 18(333-351).

Mullis, J., Dubessy, J., Poty, B. and O'Neil, J., 1994. Fluid regimes during late stages of a continental collision: Physical, chemical, and stable isotope measurements of fluid inclusions in fissure quartz from a geotraverse in the Central Alps, Switzerland. Geochim. Cosmochim. Ac., 58: 2239-2267.

Murata, A., 1997. Geological map of Miyazaki prefecture, 1:200,000. Miyazaki Prefectural Government.

Peacock, S.M., 1990. Fluid processes in subduction zones. Science, 248(4953): 329-337.

Philippot, P. and Selverstone, J., 1991. Trace-element-rich brines in eclogitic veins: implications for fluid composition and transport during subduction. Contrib. Mineral. Petrol., 106: 417-430.

Raimbourg, H. et al., 2014a. Long-term evolution of an accretionary prism: the case study of the Shimanto Belt, Kyushu, Japan. Tectonics, 33: 1-24.

Raimbourg, H. et al., 2014b. A new method of reconstituting the P-T conditions of fluid circulation in an accretionary prism (Shimanto, Japan) from microthermometry of methane-bearing aqueous inclusions. Geochim. Cosmochim. Ac., 125: 96-109.

Rollion-Bard, C., Mangin, D. and Champenois, M., 2007. Development and application of oxygen and carbon isotopic measurements of biogenic carbonates by ion microprobe. Geostandards and geoanalytical research, 31: 39-50.

Rumyantsev, V.N. and Novozhilov, A.I., 1980. Dependence of concentration of aluminum centers and anomalous pleochroism on certain crystallization parameters in synthetic quartz. Soviets Physics-Crystallography, 25(1): 75-78.

Sadofsky, S.J. and Bebout, G.E., 2001. Paleohydrology at 5- to 50-kilometer depths of accretionary prisms: The Franciscan Complex, California. Geophys. Res. Lett., 28(12): 2309-2312.

Sadofsky, S.J. and Bebout, G.E., 2004. Field and isotopic evidence for fluid mobility in the Franciscan Complex: forearc paleohydrogeology to depths of 30 kilometers. Int. Geol. Rev., 46(12): 1053-1088.

Saffer, D. and McKiernan, A.W., 2009. Evaluation of in situ smectite dehydration as a pore water freshening mechanism in the Nankai Trough, offshore southwest Japan. Geochem. Geophys. Geosystems, 10(2): 1-24.

Saffer, D. and Tobin, H.J., 2011a. Hydrogeology and mechanics of subduction zone forearcs: Fluid flow and pore pressure. Ann. Rev. Earth Planet. Sci., 39: 157-186.

Saffer, D. and Tobin, H.J., 2011b. Hydrogeology and mechanics of subduction zone forearcs: 
Fluid flow and pore pressure. Ann. Rev. Earth Planet. Sci., 39(157-186).

Saffer, D.M. and Bekins, B.A., 1998. Episodic fluid flow in the Nankai accretionary complex:

Timescale, geochemistry, flow rates and fluid budget. J. Geophys. Res., 103(B12): 30,351-30,370.

Saffer, D.M. and Bekins, B.A., 2006. An evaluation of factors influencing pore pressure in accretionary complexes: Implications for taper angle and wedge mechanics. J. Geophys. Res., 111: doi:10.1029/2005JB003990.

Sakaguchi, A., 1999. Thermal maturity in the Shimanto accretionary prism, southwest Japan, with the thermal change of the subducting slab: Fluid inclusion and vitrinite reflectance study. Earth Planet. Sci. Lett., 173: 61-74.

Sato, T. and Takahashi, M., 1997. Geochemical changes in anomalously discharged groundwater in Awaji Island-after the 1995 Kobe earthquake. Chikyukagaku, 31: 89-98.

Scambelluri, M. and Philippot, P., 2004. Volatile and mobile element recycling during subduction of the oceanic lithosphere. Insights from metasediments and serpentinites of the Alps. Periodico di mineralogia, 73(2): 221-233.

Shipboard Scientific Party, 1988. Site 672. In: A. Mascle, J.C. Moore and et al. (Editors), Proc. ODP, Init. Repts, vol 110, pp. doi:10.2973/odp.proc.ir.156.107.1995.

Shipboard Scientific Party, 2001. Site 1173. In: G.F. Moore et al. (Editors), Proc. ODP, Init. Repts, College Station, TX (Ocean Drilling Program), pp. 1-147. doi:10.2973/odp.proc.ir.190.104.2001.

Shipboard Scientific Party, 2003a. Site 1225. In: S.L. D'Hondt, B.B. Jorgensen and D.J. Miller (Editors), Proc. ODP, Init. Rpts, vol. 201, pp. 1-86.

Shipboard Scientific Party, 2003b. Site 1226. In: S.L. D'Hondt, B.B. Jorgensen and D.J. Miller (Editors), Proc. ODP, Init. Rpts, vol. 201, pp. 1-96.

Shipboard Scientific Party, 2003c. Site 1231. In: S.L. D'Hondt, B.B. Jorgensen and D.J. Miller (Editors), Proc. ODP, Init. Rpts, vol. 201, pp. 1-64.

Shipboard Scientific Party, 2003d. Site 1254. In: J.D. Morris, H.W. Villinger, A. Klaus and e. al. (Editors), IODP Proc., Init. Rpts. vol. 205, pp. 1-113.

Sibson, R.H., 1975. Generation of pseudotachylyte by ancient seismic faulting. Geophys. J. R. Astron. Soc., 43: 775-794.

Song, I. and Renner, J., 2008. Hydromechanical properties of Fontainebleau sandstone: experimental determination and micromechanical modeling. J. Geophys. Res., 113(B09211).

Steurer, J.F. and Underwood, M., 2005. Clay mineralogy of mudstones from the Nankai Trough references sites 1173 and 1177 and frontal accretionary prism site 1174. In: H. 
Mikada et al. (Editors), Proc. ODP, Sci. Results, 190/196, pp. 1-37. doi:10.2973/odp.proc.sr.190196.211.2003.

Suarez-Rivera, R. and Fjaer, E., 2013. Evaluating the poroelastic effect on anisotropic, organic-rich, mudstone systems. Rock Mech. Rock Eng., 46: 569-580.

Taira, A., Katto, J., Tashiro, M., Okamura, M. and Kodama, K., 1988. The Shimanto Belt in Shikoku, Japan--Evolution of Cretaceous to Miocene accretionary prism. Modern Geology, 12: 5-46.

Tajima, F., Mori, J. and Kennet, B.L.N., 2013. A review of the 2011 Tohoku-Oki earthquake (Mw 9.0): Large-scale rupture across heterogeneous plate coupling. Tectonophysics, 586: 15-34.

Toriumi, M. and Teruya, J., 1988. Tectono-metamorphism of the Shimanto Belt. Modern Geology, 12: 303-324.

Tsinober, L.I. and Kamentsev, I.E., 1964. Effect of growth rate on the concentration of smoky color and on the unit cell parameters of synthetic quartz crystals. Soviets Physics-Crystallography, 9(3): 374-376.

Tsuji, T. et al., 2006. Modern and ancient seismogenic out-of-sequence thrusts in the Nankai accretionary prism: Comparison of laboratory-derived physical properties and seismic reflection data. Geophys. Res. Lett., 33: 1-5.

Tsuneishi, Y. and Nakamura, K., 1970. Faulting associated with the Matsuhiro Swarm Earthquake. Bulletin of the Earthquake Research Institute, 48: 29-51.

Van Keken, P.E., Hacker, B.R., Syracuse, E.M. and Abers, G.A., 2011. Subduction factory: 4. Depth-dependent flux of $\mathrm{H} 2 \mathrm{O}$ from subducting slabs worldwide. J. Geophys. Res., 116(B01401): 1-15.

Velde, B. and Vasseur, G., 1992. Estimation of the diagenetic smectite to illite transformation in time-temperature space. Am. Mineral., 77: 967-976.

Von Huene, R. and Lallemand, S., 1990. Tectonic erosion along the Japan and Peru convergent margins. GSA Bull., 102(6): 704-720.

Vrojlik, P., 1987. Tectonically-driven fluid flow in the Kodiak accretionary complex, Alaska. Geology, 15: 466-469.

Vrolijk, P., 1987. Paleohydrogeology and fluid evolution of the Kodiak accretionary complex, Alaska. Ph.D. Thesis, University of California, Santa Cruz, 232 pp.

Vrolijk, P., Chambers, S.R., Gieskes, J.M. and O'Neil, J., 1990. Stable isotope ratios of interstitial fluids from the Northern Barbados accretionary prism, ODP Leg 110. In: J.C. Moore and et al. (Editors), Proc. ODP, Sci. Results, pp. 181-205.

Vrolijk, P., Myers, G. and Moore, J.C., 1988. Warm fluid migration along tectonic melanges in the Kodiak accretionary complex, Alaska. J. Geophys. Res., 93: 10,313-10,324. 
Wilson, D.S. and et. al., 2006. Drilling to gabbro in intact oceanic crust. Science, 312: 1016-1020.

Yamaguchi, A., Cox, S.F., Kimura, G. and Okamoto, S., 2011. Dynamic changes in fluid redox state associated with episodic fault rupture along a megasplay fault in a subduction zone. Earth Planet. Sci. Lett., 302: 369-377. 


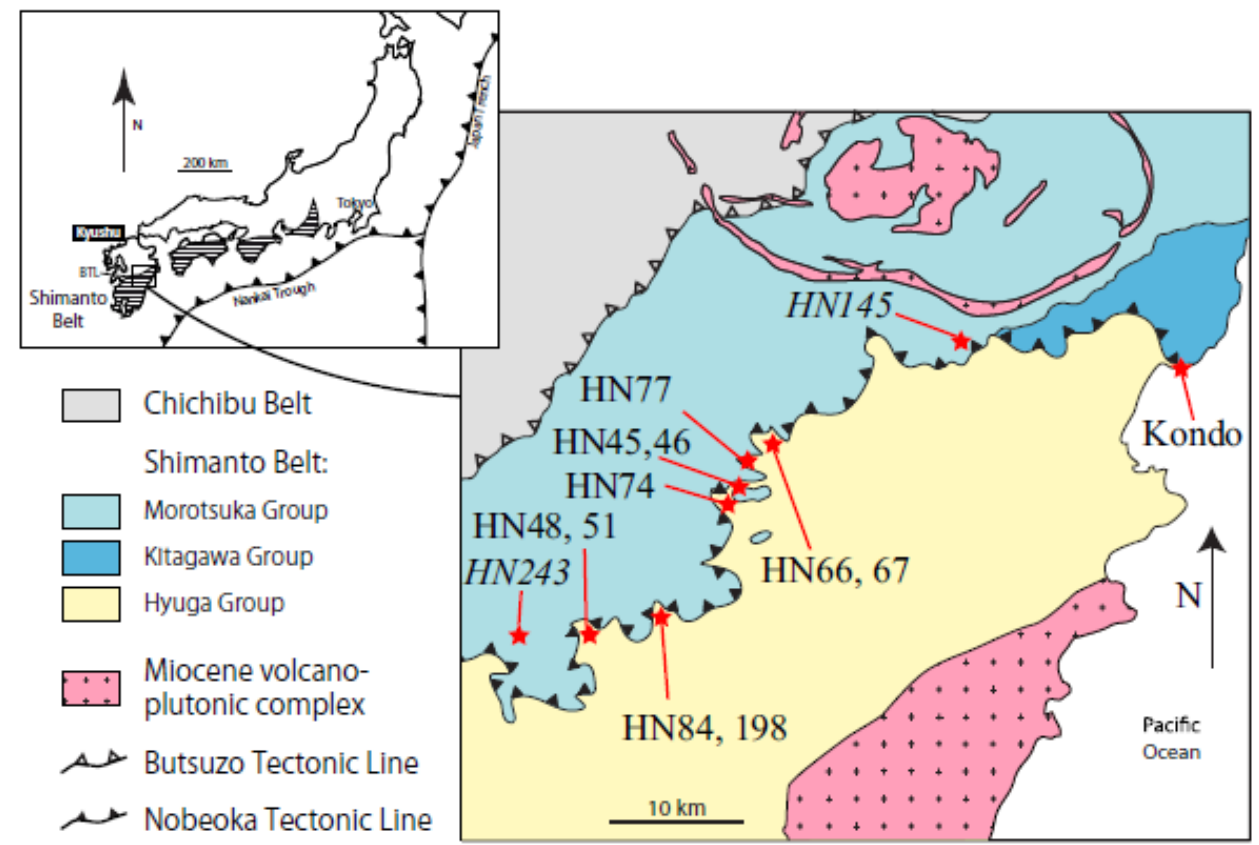

Figure 1 

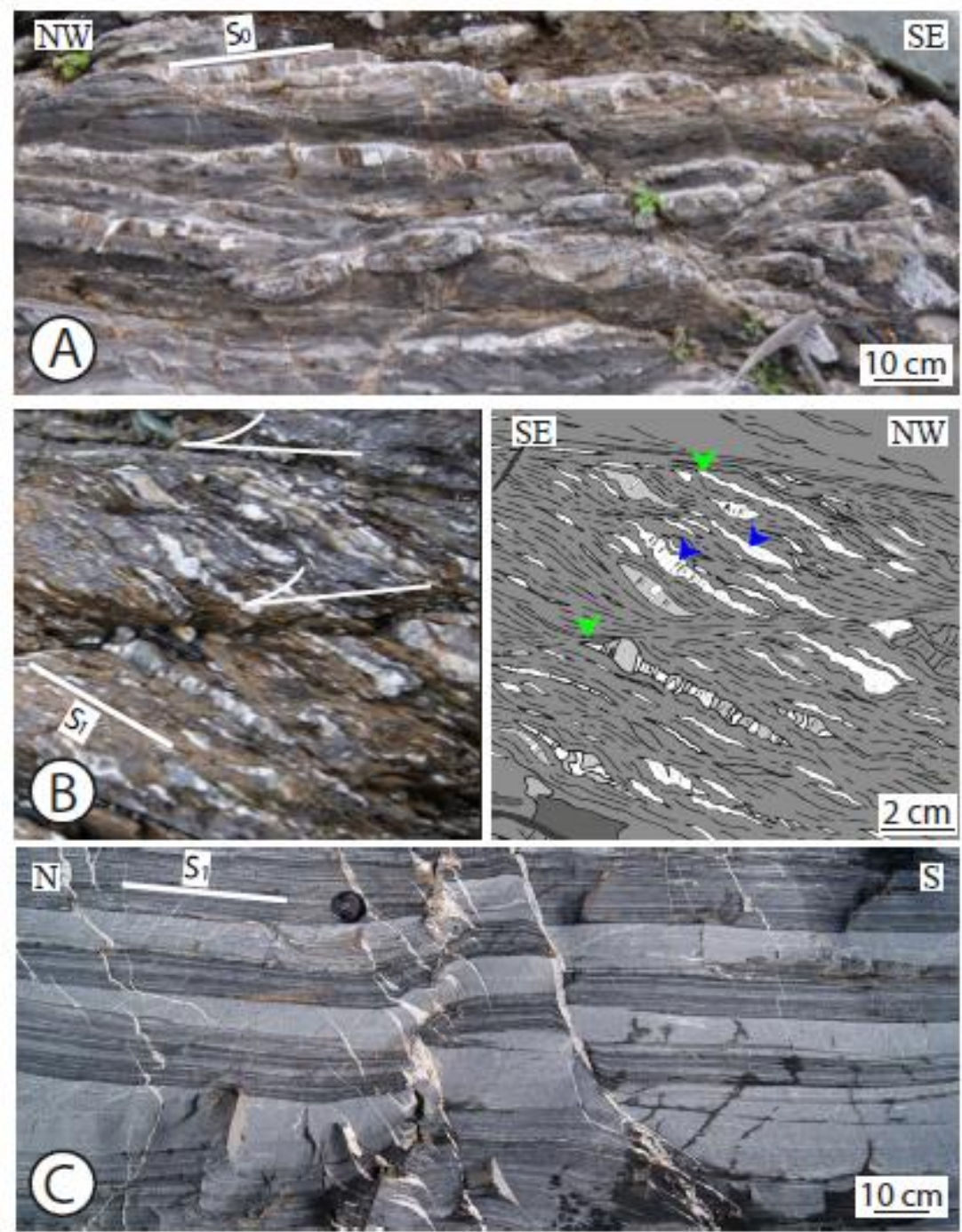

Figure 2 

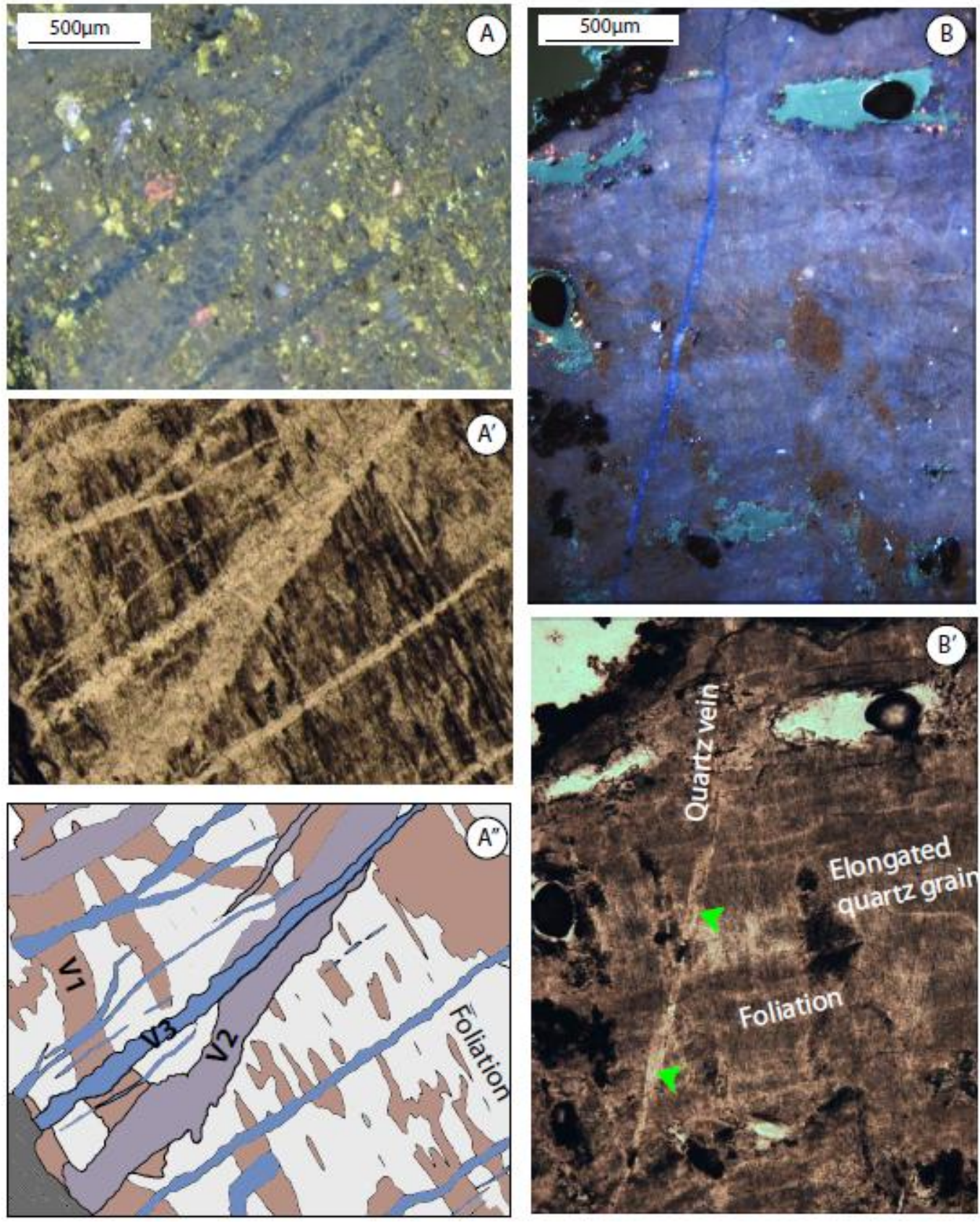

Figure 3 


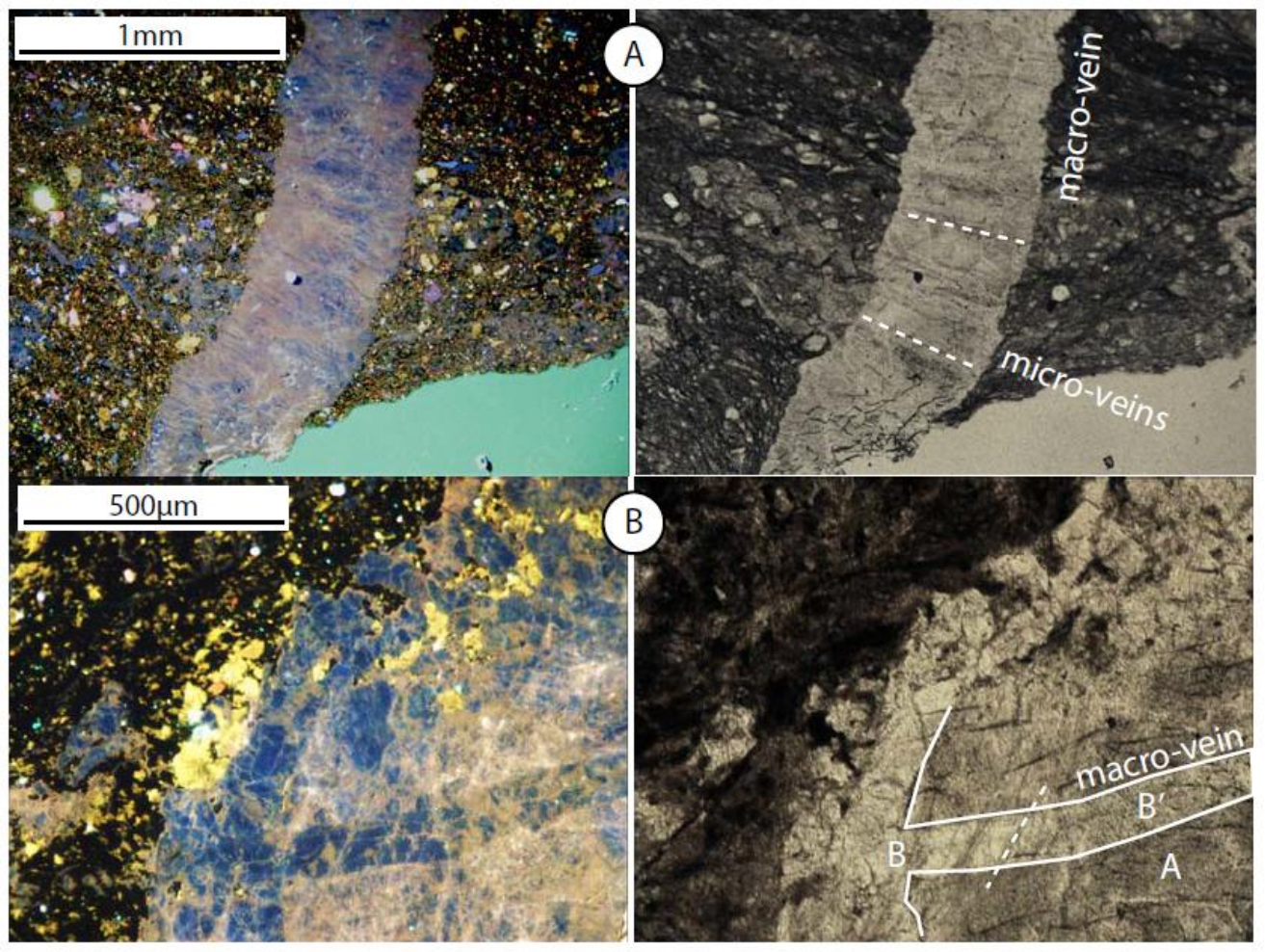

Figure 4 


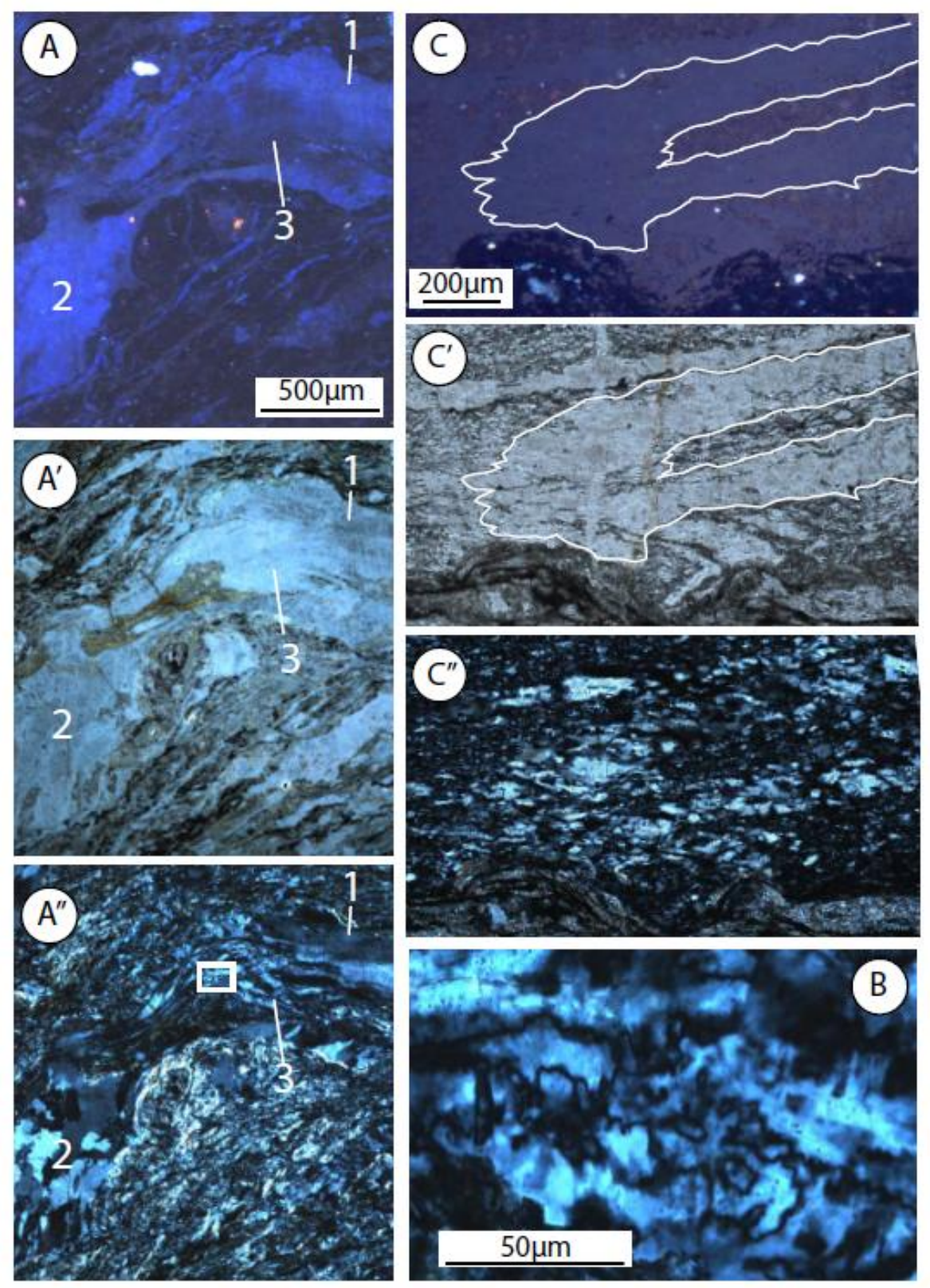

Figure 5 

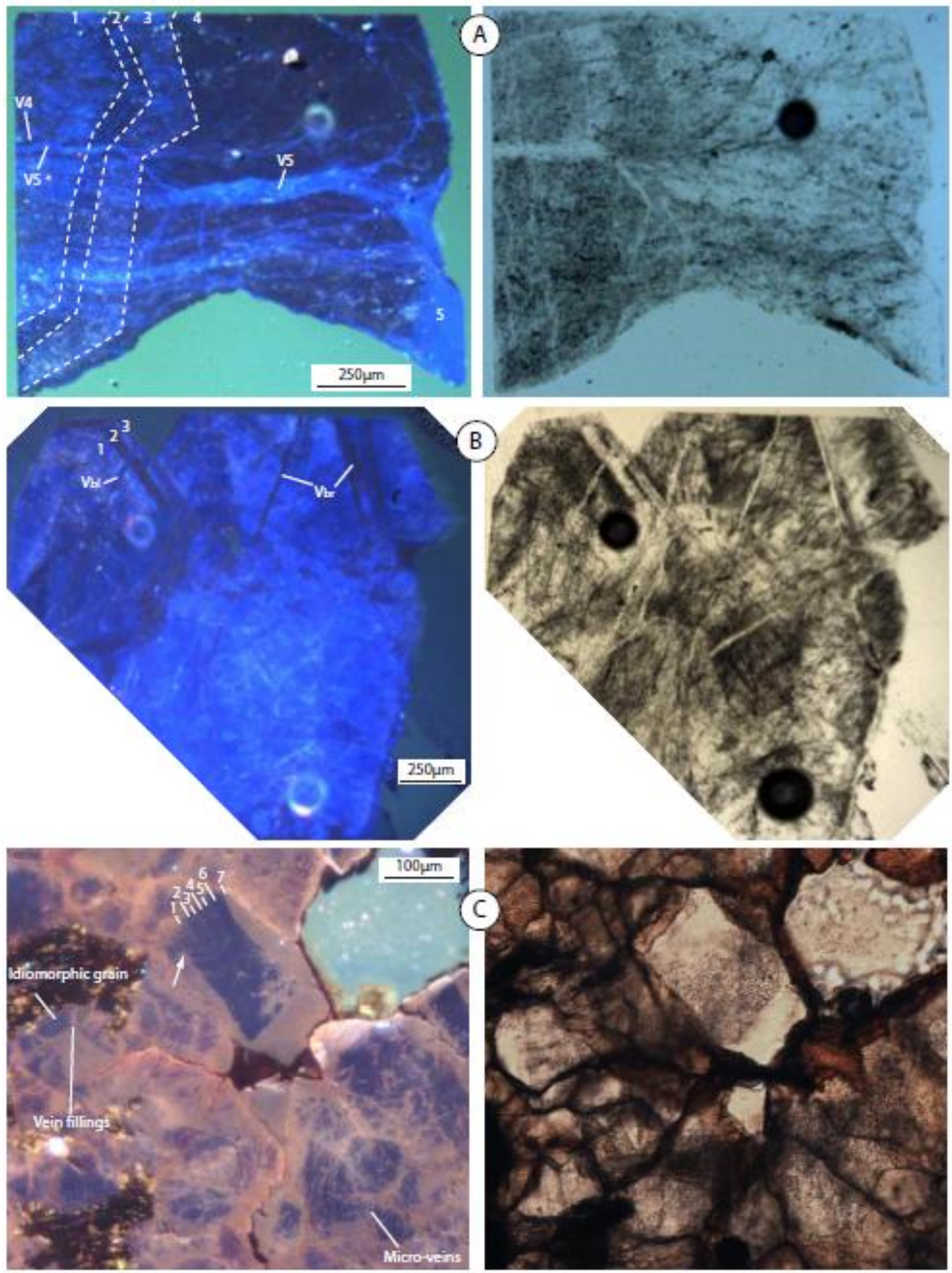

Figure 6 

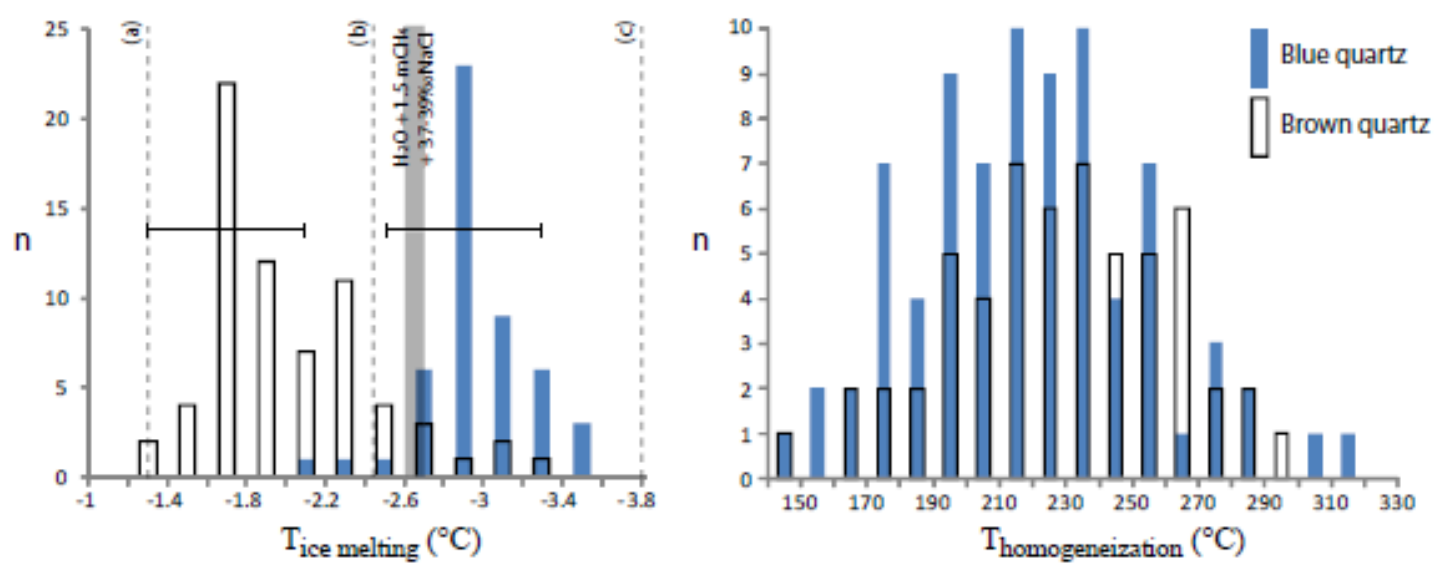

Figure 7 

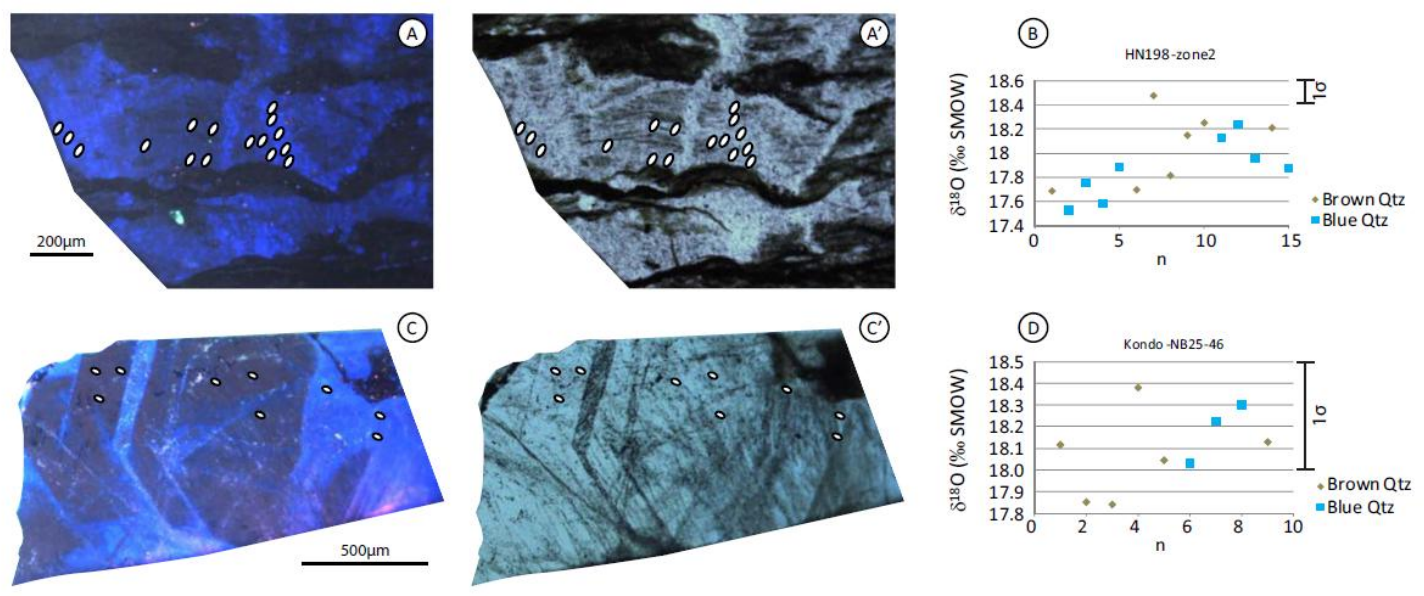

Figure 8 


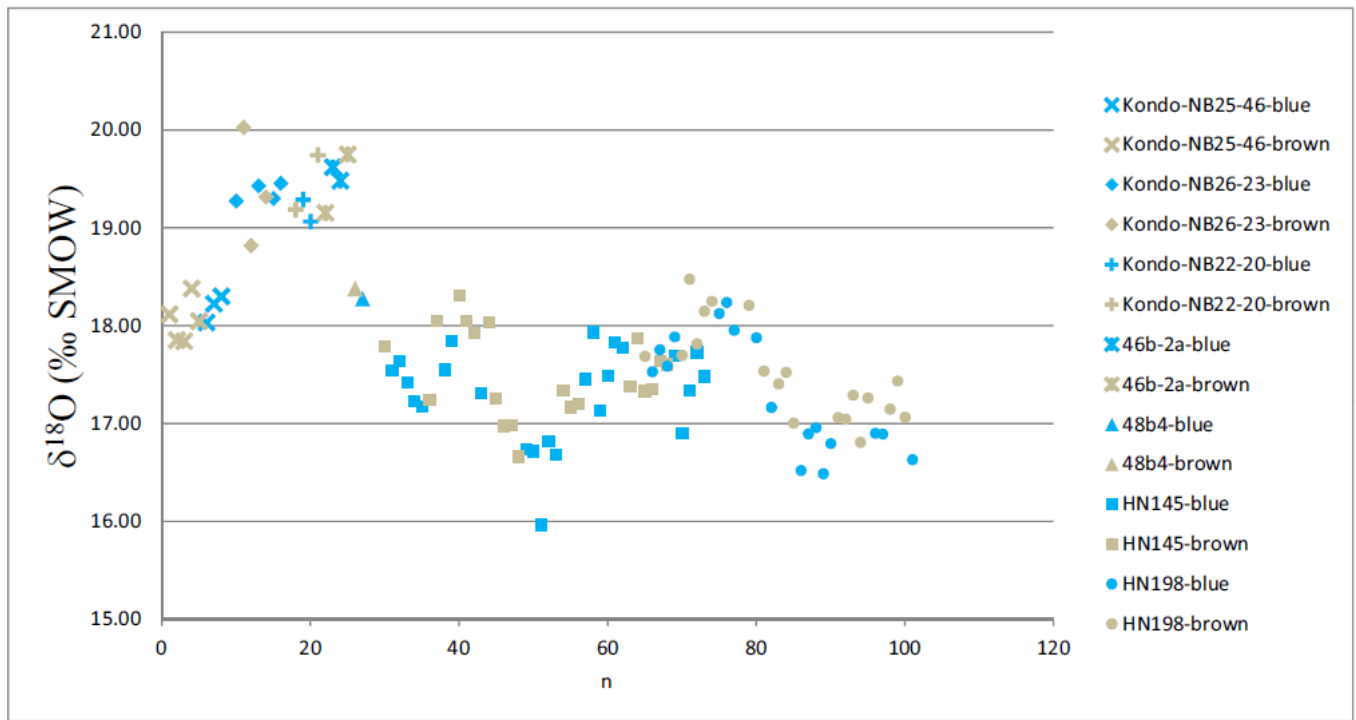

Figure 9 

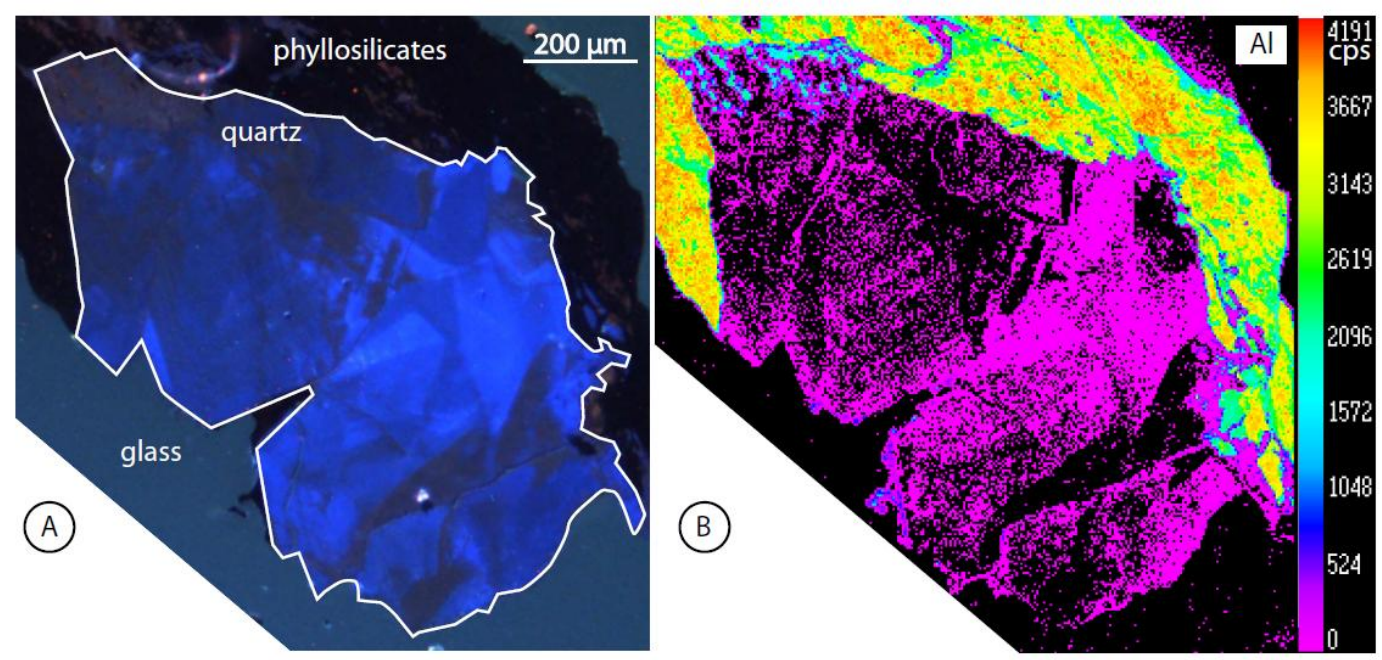

Figure 10 


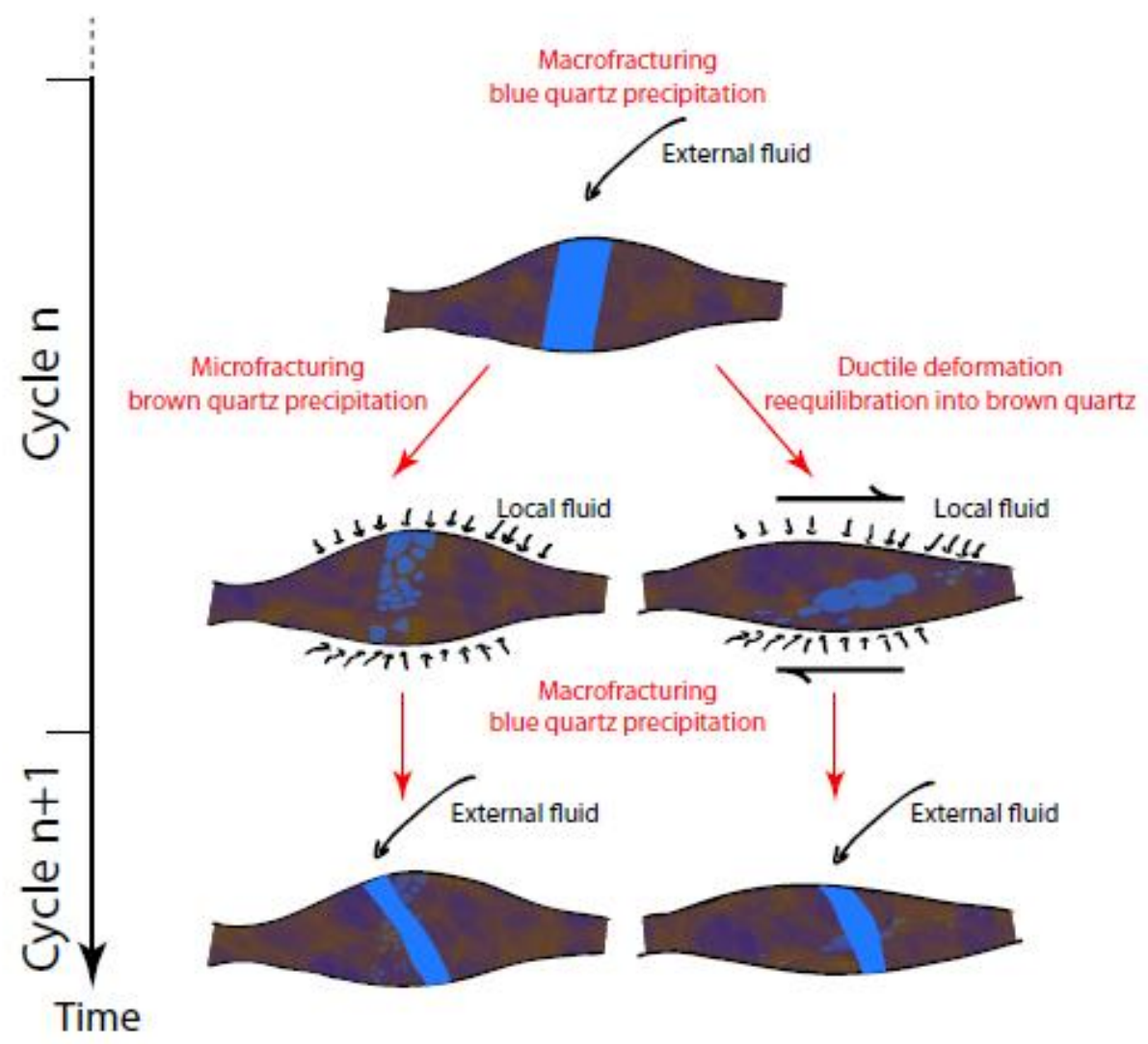

Figure 11 


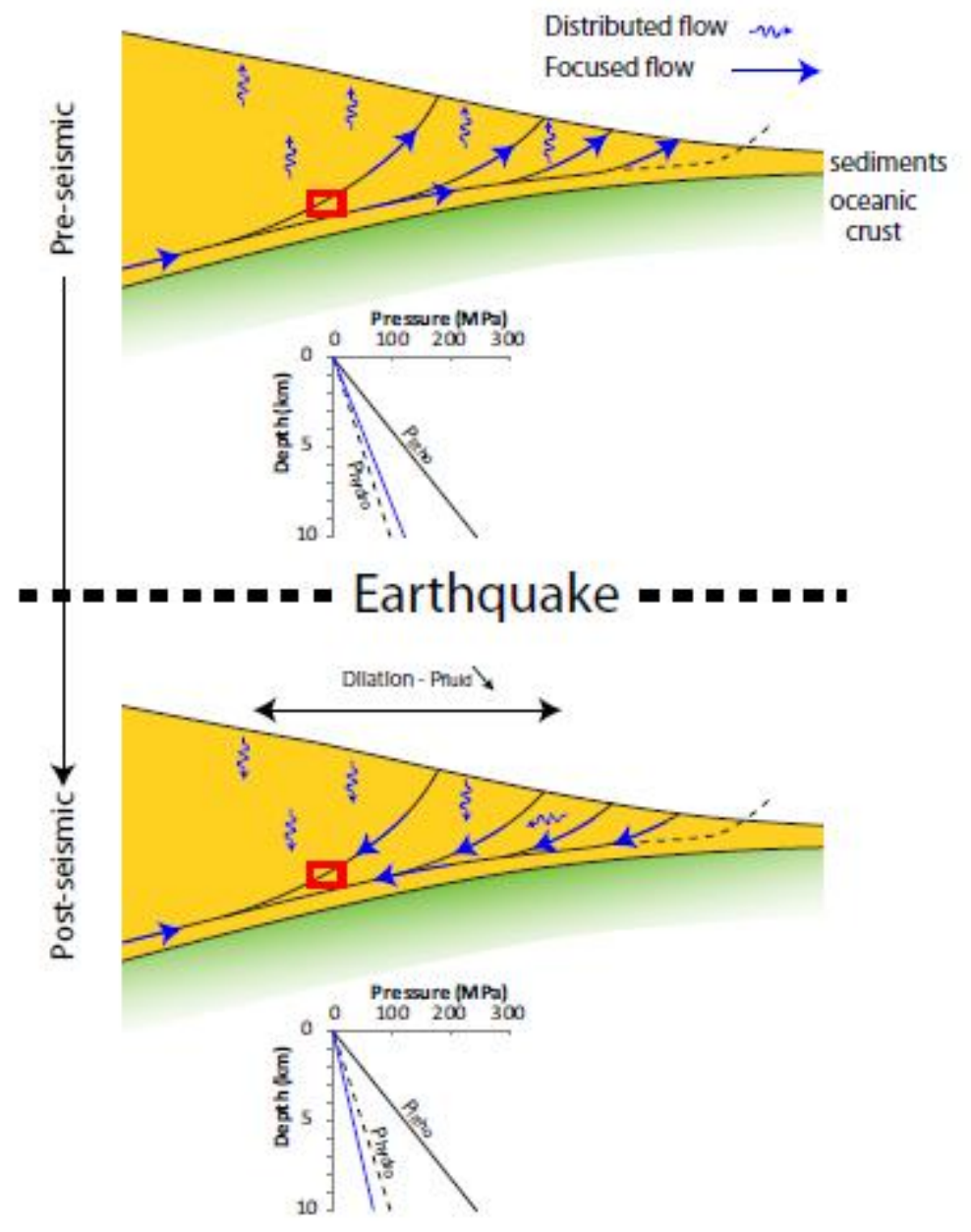

Figure 12 


\section{Highlights}

Two distinct fluids unraveled from deep quartz veins in a fossil accretionary prism

Local fluid intermittently replaced by pulses of external fluid with higher salinity

$\delta^{18} \mathrm{O}$ signature of the fluid is lost by reequilibration; salinity and aluminum signatures much more persistent.

The source of the saline, external fluid is shallow water percolated to depth. 